\title{
Re-conceptualizing Classroom Assessment Fairness: A Systematic Meta-ethnography of Assessment Literature and Beyond
}

\author{
A. Rasoolia, H. Zandi, \& C. DeLuca ${ }^{a}$ \\ ${ }^{a}$ Faculty of Education, Queen's University, Kingston, Canada \\ ${ }^{b}$ Institute for Advanced Studies in Basic Sciences, Iran
}

Full Citation:

Rasooli, A. H., Zandi, H., \& DeLuca, C. (2018). Re-conceptualizing classroom assessment fairness: A systematic meta-ethnography of assessment literature and beyond.

Studies in Educational Evaluation, 56, 164-181.
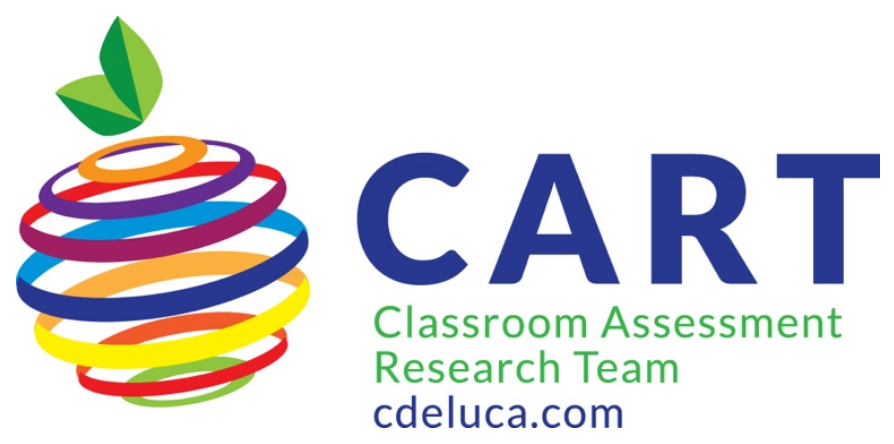

\author{
Contact: \\ Christopher DeLuca \\ cdeluca@queensu.ca \\ @ChrisDeLuca20
}




\begin{abstract}
Conceptualizing fairness in student assessment at classroom levels has been an area of focus in recent years given the growing emphasis on assessment-driven teaching and educational accountability across educational systems. However, previous studies into assessment fairness have predominantly drawn on assessment-based literature to conceptualize fairness. While this literature is central to the construct, we argue that it does not fully account for the dynamic relationship between assessment, teaching, and learning within the diverse socio-cultural classroom contexts. Therefore, using a systematic meta-ethnographic review of 150 studies, this study identifies a more comprehensive conception of fairness for classroom assessment drawn from not only assessment literature but also from literature beyond assessment, which has not already been included in the process of reconceptualizating classroom assessment fairness. The results of this study present a conceptualization of classroom assessment fairness with a dominant focus on the role of assessment fairness in supporting student learning. Keywords: Fairness, Classroom assessment, Meta-ethnography, Systematic review
\end{abstract}


Fairness has consistently been emphasized in classroom assessment (CA) standards and practices as an essential quality and a significant dimension of teachers' assessment literacy (DeLuca, 2012; DeLuca, LaPointe-McEwan, \& Luhanga, 2016; Xu \& Brown, 2016). Empirical studies have demonstrated that teachers' fairness practices are associated with positive learning effects for students such as cognitive learning (Holmgren \& Bolkan, 2014; Molinari, Speltini, \& Passini, 2013), instructor satisfaction (Wendorf \& Alexander, 2005), self-efficacy (Vallade, Martin, \& Weber, 2014), legitimation of teacher and school authority (Gouveia-Pereira, Vala, Palmonari, \& Rubini, 2003; Nelson, Shechter, \& Ben-Ari, 2014), political trust (Abdelzadeh, Zetterberg, \& Ekman, 2015), and positive evaluation of teacher expertise (Cronen \& Fuller, 1976; Gotlieb, 2009; Rodabaugh \& Kravitz, 1994). In contrast, perceived unfair behavior is associated with outcomes such as aggression and hostility (Horan, Chory, Carton, Miller, \& Raposo, 2013; Uludag, 2014), truancy (Ishak \& Fin, 2013), headache (Lenzi et al., 2013), and cheating (Lemons, Martin, \& Seaton, 2011). Unfortunately, research has repeatedly found that students report high levels of unfairness during assessment processes (Buttner, 2004; Čiuladienė \& Račelytè, 2016). Despite repeated calls for teachers to enact fair assessments (Sanders et al., 1990; Scott, Webber, Lupart, Aitken, \& Scott, 2014; Tierney, 2013), researchers have argued that compared to other fundamental aspects of assessment (i.e., validity and reliability), there has been limited conceptualizations of fairness for CA contexts (Tierney, 2013). Moreover, research has revealed that teachers across contexts lack consensus on what they consider as fair assessment practices (Green, Johnson, Kim, \& Pope, 2007; Liu, Johnson, \& Fan, 2016). In an effort to define CA fairness, several researchers have empirically examined teachers' perspectives and practices (Green et al., 2007; Liu et al., 2016; Tierney, 2014). As an example, Green et al. (2007), building on the previous conceptualizations of fairness in 
psychometrics and large-scale assessment, constructed items to measure teachers' ethical and fair dilemmas predominantly in summative assessment. They found that teachers held high agreement in items related to communication about grading, confidentiality, and multiple assessment opportunities but had low agreement on items related to standardized test administration, grading practices, and addressing biases.

Another researcher, Tierney (2014), disillusioned by the extant conceptualizations of CA fairness predicated on a large-scale psychometric tradition, adopted an inductive approach to conceptualize CA fairness by studying teachers' perspectives. Drawing on the results of her interviews with teachers, she suggested that teachers associate CA fairness with issues such as constructive classroom environment, transparent communication, equity and equality, and reflective thinking. Tierney's findings suggest that conceptualizing fairness through psychometric and large-scale traditions maintains conventional distinctions between assessment and teaching while the classroom presents a different context for the enactment of fairness. Accordingly, CA fairness needs to align with CA theory and definition and be reconceptualized towards what Brookhart (2003) calls classroometric theory.

In this study, we approach $\mathrm{CA}$ as a broad and evolving conceptualization of a process that teachers and students use in collecting, evaluating, and using evidence of student learning for a variety of purposes, including diagnosing student strengths and weaknesses, monitoring student progress toward meeting desired levels of proficiency, assigning grades, and providing feedback to parents. (McMillan, 2013, p. 4)

In this conceptualization, teachers and students play active roles in selecting and constructing opportunities for assessment that both formatively support and motivate learning as 
well as summatively gauge learning progress. In addition, contemporary notions of formative assessment, or assessment for learning, further emphasize student-involved assessments that engage them in self- and peer-assessment processes that stimulate learning of content and selfregulation skills. Collectively, this conceptualization of CA is rooted in a socio-cultural understanding in which assessment is a dynamic process shaped by teachers, students, curriculum, pedagogy, and the learning culture (Cowie, 2015; Cowie \& Bell, 1999; Klenowski, 2009; Shepard, 2001).

Building on this definition and compared to large-scale assessment contexts, central to classroom contexts are two distinct but key priorities: (a) assessment is used to not only for accountability purposes but also to support student learning (Wiliam, 2011; Assessment Reform Group, 2002), and (b) assessment is highly integrated with teaching and must consider the social, cultural, and relational dimensions of classrooms (Cowie, 2015; Klenowski, 2009; Tierney, 2016). McMillan (2013) further distinguishes CA from large-scale and standardized assessments, by noting it is "locally controlled and consists of a broad range of measures....as well as informal ways of collecting evidence. It is more than mere measurement or quantification of student performance" (p. 4). Therefore, solely adopting a psychometric paradigm to study CA fairness would overlook the wide range of CA practices that the dynamics of a classroom might bring to the table.

While previous CA researchers have begun to shed light on a classroom-centric conceptualization of assessment fairness, the majority of previous studies have drawn primarily on assessment literature to characterize fairness. This paper marks a further attempt to conceptualize CA fairness by systematically reviewing the literature of classroom fairness not only from an assessment point of view, but more importantly from the point of view of justice 
researchers in education and related fields, which has not already been included in the process of reconceptualizing CA fairness. Hence, the overarching purpose of this study is to propose a conceptualization of CA fairness by identifying fairness themes from both assessment and nonassessment literature.

\section{Method}

\section{Search and Selection Process}

A systematic meta-ethnography can help construct conceptual frameworks for complex constructs, such as CA fairness, by critically and systematically examining literature across relevant domain areas (Nye, Melendez-Torres, \& Bonell, 2016). Therefore, a systematic metaethnography was used to guide the selection, review, and synthesis of individual studies across assessment- and non-assessment educational literature domains to construct a CA fairness conceptualization for this study.

A four-phase approach was adopted to select studies for inclusion. In phase 1, to find relevant literature, several keywords were identified after an initial scan of the available studies on fairness with a focus on education, classrooms, and assessment. Primary keywords included fairness, classroom, education, and assessment with additional proxy keywords of objectivity, bias, values, ethics, equality, equity, equitable, and justice. Building on these keywords, Google Scholar database was searched using the following terminologies: 'bias in classroom assessment', ‘classroom justice', ‘equality in classroom', ‘equity in classroom', objectivity in classroom', 'fairness and classroom', 'fairness and classroom assessment', 'ethics in classroom', 'values in classroom assessment', and 'equitable assessment'. This search retrieved 8,549 studies. A temporal period was not included in the search software to comprehensively identify relevant studies in both $\mathrm{CA}$ and beyond assessment literature. 
In phase 2 , the 8,549 publications were subjected to a selection process. After screening the titles, two researchers systematically and collectively excluded studies that (a) did not include the fairness keywords identified above in their titles, and that did not appear to focus on fairness issues $(n=4,985)$, and (b) used fairness keywords in their titles but were not conducted in education and related fields $(n=2,043)$.

Reviewing the abstracts of the remaining 1,521 studies, two researchers systematically and collectively excluded two groups of sources. First, 1,143 sources that dealt with issues of social justice, equity, fairness, ethics, inclusion, morality, and democracy in instructional contexts and domains beyond the classroom as the present study aimed to focus on fairness inside the classroom context, and contribute to how fairness can be enhanced for the majority of students rather than for specific groups such as disability students and English learners. Nonetheless, studies that focused on accommodation for these two groups were included because accommodation has previously been emphasized as a fairness issue in the CA standards (DeLuca et al., 2016). Second, since the nature of CA fairness is different from fairness in large-scale traditions (Camilli, 2013; Tierney, 2014), studies $(n=128)$ that examined fairness in standardized testing contexts were excluded.

Finally, full texts of the remaining studies $(n=250)$ that solely focused on classroom fairness were retrieved barring for the ones that were (a) unavailable via web access $(n=48)$, or (b) books, non-peer-reviewed papers, conference papers, news, institutional documents, book reviews, editorial of special issues, theses, and dissertations $(n=95)$. Therefore, a total number of 107 studies, including book chapters and peer-reviewed papers were included in this review. In following best practices for meta-ethnographies as suggested by Nye et al. (2016), iterative literature searches were continued by exploring the three additional educational databases of 
Education Source, ERIC, and PsycINFO. Comparing studies retrieved through the Google Scholar search with articles retrieved through these databases, an additional 17 relevant studies were identified. Tracking of references of the included studies from both Google Scholar and Educational databases led to the identification of additional 26 relevant studies. As a result, a total of 150 sources were identified that met the search criteria for this study.

\section{Data Analysis}

In phase 3, the 150 studies were categorized into two groups: assessment and nonassessment, based on three criteria: (a) whether the study had been written with a focus on fairness within (or outside of) the scope and interest of educational assessment; (b) if the study was published in (non-) assessment journals; and (c) if the study had been carried out by an assessment specialist(s). The journal scope and author specialization were determined by checking the website of journals and authors' affiliations as outlined in the manuscripts and in the university profiles. Taken together, these three criteria helped determine if a study was grounded in the literature of assessment or non-assessment as the purpose of this study was to realize the current literature of fairness in classroom assessment and then reconceptualize it by drawing on fairness literature in the general education domain. The three researchers each read and classified the studies using the classification criteria. In the few cases of misclassification, the researchers discussed the article in relation to the criteria until consensus was reached. A total of 50 studies were found as related to assessment fairness and 100 to classroom fairness from general education literature (see Table 1 and 2 for summary of studies).

In the final phase, all 50 studies in the assessment category were inductively analyzed and thematically coded to identify themes related to CA fairness. In order to generate the themes, the summary of the major findings in each manuscript was read and reread. These readings 
provided the codes that represented the key threads and issues in each study. A code list was generated and the three researchers applied this code list to all article summaries. The researchers compared their application of the code list across the summaries. In cases of misaligned coding, researchers discussed the purpose, method, and findings of the article in relation to the codes until consensus was reached. This process yielded a high degree of inter-rater agreement in the analysis process.

The codes were then compared and contrasted across all the manuscripts to identify the constellation of studies with similar codes. These constellation of studies with common codes were assigned overarching themes that broadly represented the set of codes. In cases where three researchers disagreed on a theme, they discussed the codes and themes until consensus was reached.

The following major themes for assessment fairness were identified through the above procedure: (a) opportunity for learning and access to demonstrate learning; (b) transparency, consistency and justification; (c) accommodations; (d) do no harm and constructive classroom environment; (e) avoid score pollution; and (f) group work and peer assessment. Table 1 lists these themes with the number of CA studies that identified them. Some of the studies were included under several themes.

\section{INSERT TABLE 1 HERE}

A similar approach was adopted to thematically and inductively analyze 100 studies in classroom fairness. The following major themes were identified for classroom fairness: (a) sex bias; (b) distributive justice; (c) procedural justice; (d) interactional justice; (e) pedagogy; (f) students' fairness-related beliefs; (g) group work and peer assessment; and (h) instructional accommodation. Table 2 presents these themes and the number of studies that identified them. Some of the studies were included under several themes. 
INSERT TABLE 2 HERE

Finally, demographic information related to the context of studies, time of publication, and research design were coded, as presented in Table 1 and 2. These tables reveal that most of the fairness studies (assessment and non-assessment based) were conducted in the US (41.3\%), with additional work conducted in the UK (4.6\%), Germany (3.3\%), Israel (3.3\%), Canada (3.3\%) and Australia (2.6\%). However, a significant proportion of studies were also theoretical (24\%), which means that they were not data-driven (i.e. empirical) or they were reviews of the literature in a few cases. Information related to the time of publication also indicates a recent increase in publications on fairness in both assessment and non-assessment literature, but to a lesser extent in non-assessment literature.

With respect to research design of assessment fairness studies, 38\% were theoretical, $34 \%$ were quantitative, $22 \%$ were qualitative, and $6 \%$ employed mixed methods. The percentage of research designs for classroom fairness studies were as follows: $17 \%$ theoretical, $65 \%$ quantitative, $9 \%$ qualitative, and $9 \%$ mixed methods. This pattern demonstrates that assessment fairness and classroom fairness have been mostly examined through quantitative and theoretical approaches.

\section{Findings}

The findings are presented in two parts to meet the purposes of the study. First, the 6 major themes identified for fairness within the assessment domain are discussed. Next, an additional 8 themes for fairness from literature in the non-assessment domain are reviewed. Combined, these two sets of themes represent potential dimensions for the conceptualization of fairness as relevant to contemporary classroom assessment activities.

\section{Fairness in the Assessment Domain}

Opportunity for Learning and Access to Demonstrate Learning 
Opportunity for learning and access to demonstrate learning have been dominant concepts in the assessment fairness literature. The concept of opportunity to learn appears to hold three interpretations. The first relates to whether or not students have had access to quality resources (e.g., competent teachers and proper facilities) in order to learn content and prepare for assessments (Gipps, 1995; Gipps \& Stobart, 2009). The second, which is associated with summative assessment, considers whether or not students have had access to test content and material before the classroom, district, or state testing event (Gipps, 1995; Gipps \& Stobart, 2009; Tierney, 2013, 2016). In these two interpretations, equality of access is regarded as fair because students' performances on summative tests can be traced back to differences in learning opportunities (Gipps \& Stobart, 2009). The third interpretation, which aligns with instruction and formative assessment, argues for the need for varied learning opportunities in responses to students' differential learning abilities, styles, and exceptionalities (Lantolf \& Poehner, 2013; Poehner, 2011; Tierney, 2013, 2014; Yung \& Yung, 2001). In this interpretation, equitable and differentiated instruction of students based on need is considered fair because each student should have the resource or opportunity to help him or her succeed in learning (Lantolf \& Poehner, 2013; Poehner, 2011).

Compared to opportunity to learn, which typically considers fairness prior to assessment and which is closely aligned with instruction, the theme of access to demonstrate learningproviding students with "multiple, varied, equitable, and meaningful opportunities to demonstrate their learning" (Tierney, 2016, p.6) - has typically been characterized in terms of assessment opportunities that students are provided with to demonstrate what they know or can do (Camilli, 2006, 2013; Cowie, 2015; Duffield \& Spencer, 2002; Murillo \& Hidalgo, 2017; Suskie, 2000; Tierney, 2013; Volante, 2006). The empirical studies have also demonstrated that 
students feel treated fairly when provided with multiple assessment opportunities (Duffield \& Spencer, 2002; Mauldin, 2009). Similar to the last interpretation of opportunity to learn, equitable, differentiated, and multiple assessments of students are regarded fair in the opportunity to demonstrate learning theme. Building on these two themes, fairness in a CA context needs to consider both the instructional conditions (i.e., opportunity to learn) as well as the assessment conditions (i.e., access to demonstrate learning). Within each, there is evidence of multiple interpretations from equal treatment to an equitable stance, with the latter focusing more on providing multiple varied opportunities to learn and demonstrate learning for all students.

\section{Transparency, Consistency, and Justification}

The theme of transparency, consistency, and justification is highlighted in the literature to enhance fairness in two domains related specifically to grading criteria and feedback. Transparency in grading criteria helps students understand the learning objectives and teachers' performance expectations (Alm \& Colnerud, 2015; Camilli, 2006; Gipps \& Stobart, 2009; Lizzio \& Wilson, 2008; Morgan \& Watson, 2002; Murillo \& Hidalgo, 2017; Suskie, 2000; Tierney, 2013). As Tierney (2013) suggests, transparency can enhance students' access to opportunity to learn and opportunity to demonstrate learning by providing them with clear learning and assessment expectations.

Despite the potential benefits of transparency, Tierney (2013) raises three concerns that can negatively affect transparency in CA. First, she argues that provision of transparent learning expectations can promote the idea among teachers and students that solely the identified objectives are worth learning, which can restrict and narrow learning. Second, provision of transparent criteria and its communication are two distinct processes where failure to effectively communicate the criteria to students can threaten transparency. Third, transparency without its 
consistent application across students or student groups can adversely affect fairness, especially in graded assessments (Camilli, 2006; Morgan \& Watson, 2002). In addition to these concerns, we refer to justification, which occurs during the communication of assessment criteria and decisions. Researchers have noted that fair assessment practice involves teachers providing students with rationales giving rise to learning objectives and assessment criteria (Alm \& Colnerud, 2015; Camilli, 2006; Gipps \& Stobart, 2009; Lizzio \& Wilson, 2008; Morgan \& Watson, 2002; Murillo \& Hidalgo, 2017; Suskie, 2000; Tierney, 2013). Therefore, a cycle of providing transparent criteria, its justification, effective communication, and consistent application can serve to greatly promote fairness in CA.

Although the literature has largely focused on transparency, consistency, and justification in terms of grading criteria, far less attention has been paid to the discussion of these concepts with respect to feedback. Two qualitative studies have focused on the issue of feedback in CA, and have probed teachers and students' conceptions of effective feedback (Carless, 2006; Lizzio \& Wilson, 2008). These two studies have reported that students consider fairness as one of the significant dimensions of effective feedback, and they take into account transparency (i.e., the feedback that they can decipher its meaning and intention easily), consistency (i.e., its congruence with previous comments), and justification (i.e., provided with logical explanations) as indicators of fair feedback (Carless, 2006; Lizzio \& Wilson, 2008). There might be additional factors influencing students' perception of fair feedback such as its respectfulness, its equitable or equal distribution, and teachers' body language and tone. More research is required in this area and early efforts can be directed to explore teachers and students' conceptions of (un)fair feedback.

Accommodations 
Accommodating exceptional and English language learners (ELL) is emphasized as a fairness principle in CA standards (DeLuca et al., 2016). Abedi, Hofstetter, and Lord (2004), in their review of accommodation studies for ELL, argue that accommodations aim to present ELL and exceptional learners with a fair opportunity to demonstrate what they know, "to level the playing field, so to speak, without giving them an advantage over students who do not receive the accommodation" (p. 2). Furthermore, they maintain that, ironically, accommodations can sometimes contribute to a sense of unfairness by advantaging the accommodated students relative to the non-accommodated ones to the extent that improved performance is no longer the result of the actual knowledge and ability but the impact of accommodation.

Contrary to this interpretation, Siegel and her colleagues, in a series of studies demonstrate an alternative view of the purpose of accommodating assessments (Siegel, 2007, 2014; Siegel et al., 2014; Siegel, Wissehr, \& Halverson, 2008). Siegel et al. (2008) suggest five principles for accommodating ELL for written classroom assessments: (a) the modified test should pursue the same objectives of the original test, and language of the modified test should be congruent with the language of instruction; (b) the modified test should be congruent with the language ability and cultural background of students; (c) the modified test should not simplify cognitive and critical thinking load; (d) the modified test questions should be easy to understand; and (e) the teacher should give ELL some hints to enable them to do the task. Following this equity framework in two quantitative studies, Siegel (2007) and Siegel et al. (2014) demonstrated that both ELL and native speakers' performance enhanced significantly when provided with modified written assessment tasks. Interestingly, only 35 percent of teachers in her qualitative study, which was a report of preservice teachers' reflection of accommodation for ELL, believed that accommodations were fair (Siegel, 2014). 
In addition to the above studies, Schissel (2014) explored how administrators, teachers, and students appropriated accommodations in actual summative assessments. She found that teachers tend to provide both bilingual and special education students with a similar accommodation without attending to their specific learning needs. In a similar vein to Siegel's conception (2014), Schissel demonstrated that teachers used general accommodation for all students. These studies suggest that while accommodation, on the surface, seem to be an established principle for CA fairness (DeLuca et al., 2016; Ortiz, 2002; Scott et al., 2014), the practice of accommodation requires greater attention to respond to both teachers' perceptions of accommodations as a fair practice and their use of accommodation differentially for students' specific learning needs (Schissel, 2014; Siegel, 2007; Siegel et al., 2014).

\section{Do No Harm and Constructive Classroom Environment}

Do no harm and constructive classroom environment have been regarded as ethical and fairness themes in assessment literature (Green et al., 2007; Johnson, Green, Kim, \& Pope, 2008; Liu et al., 2016; Pope, Green, Johnson, \& Mitchell, 2009; Tierney, 2013). First introduced by Green et al. (2007) for CA fairness theory, the origin of do no harm can be traced back to the ancient Greece (Pope, et al., 2009). In assessment contexts, this theme conveys two meanings: students should be treated with respect and care (Cowie, 2015; Green et al., 2007) and students and their families should be protected from harmful personal impact of assessment process and its consequences (Green et al., 2007; Scott, et al., 2014). Previous empirical studies on teachers' ethical and fair dilemmas in CA have found that teachers report high agreements and few conflicts in the scenarios related to do no harm principles (Green, et al., 2007; Pope et al., 2009).

Do no harm is closely aligned with the theme of constructive classroom environment that has been introduced as a CA fairness principle (Tierney, 2013, 2014, 2016). It appears that the 
concept of do no harm greatly facilitates the creation of a constructive classroom environment. Tierney $(2014,2016)$ further underscores two aspects for a constructive classroom environment: power dynamics and respectful relationship. She argues that for CA to pave the way for learning, pillars of trust, respect, and care in teacher-student, and peer-to-peer relationships are essential. As a token of respectful relationship that also helps address power dynamics, valuing students' voices to engage actively in classroom decision makings (including assessment decisions) is recommended, as contemporary conceptions of CA argue that assessment is done with and for students rather than to them (Aitken, 2012; Cowie, 2015; Klenowski, 2009; Murillo \& Hidalgo, 2017; Scott et al., 2014).

Moreover, empirical studies demonstrate that listening to students' voices can (a) give them more chances to engage actively in the assessment process (Flores, Veiga Simão, Barros, \& Pereira, 2015; Murillo \& Hidalgo, 2017); (b) help appreciate the complexity of their fairness conceptions as "a fundamental aspect of assessment, the crucial importance of which is often overlooked or oversimplified from the staff perspective" (Sambell, et al., 1997, p. 362); and (c) give them the opportunity to discuss teacher's feedback (Carless, 2006; Lizzio \& Wilson, 2008). It appears that teachers can build a constructive classroom environment through respectful relationship, listening to students, and enacting the do no harm principle.

Avoid Score Pollution

First introduced by Green et al. (2007) for CA fairness theory, avoid score pollution was regarded as an offshoot of do no harm particularly for assessment. It promotes the idea that students' grades should exclude factors that are construct-irrelevant to their achievement (Downing \& Haladyna, 2004; Green et al., 2007). Unlike do no harm where teachers demonstrate general consensus, in the studies of ethical and fair CA dilemmas, teachers show 
high levels of disagreements and numerous conflicts in the scenarios associated with avoid score pollution (Green, et al., 2007; Pope et al., 2009). These controversies might arise from various sources (e.g., non-achievement factors) that teachers take into consideration as indicators of fairness of grades. For example, although very few studies have reported that teachers concur that grade decisions based on students' misbehavior and gender are unfair (Murillo \& Hidalgo, 2017; Peterson, Childs, \& Kennedy, 2004; Scott et al., 2014) other studies suggest that teachers consider factors such as effort, progress, compassion for students, desire to teach life lesson, and impact of grades on students' opportunities in their future lives as fair when deciding or adjusting grades (Alm \& Colnerud, 2015; Green et al., 2007; Murillo \& Hidalgo, 2017; Sambell, McDowell, \& Brown, 1997; Scott et al., 2014; Tierney, 2015). However, the contribution of nonachievement related factors is regarded as unfair based on the concept of avoid score pollution. The research suggests, "teachers do not have clear principles guiding them on score pollution issues" (Pope, et al., 2009, p. 780), which requires further attention in the CA fairness research to guide teachers' scoring practices. Future research should also address the veracity of this theme in relation to classroom contexts given its derivation from large-scale and psychometric traditions.

In addition, as previous studies have defined avoid score pollution as solely including 'construct-irrelevant' issues (Green et al., 2007), that is, as extraneous issues that should not count toward achievement, we believe that adding 'construct-underrepresentation', that is, failure to adequately include the relevant issues in the measurement of achievement, can also be a significant aspect of this theme (Downing \& Haladyna, 2004). Previous studies have found that students perceive unfairness when teachers base their grade decisions on insufficient, unsuitable, and insignificant data that can lead to misinterpretation of their achievement (Alm \& Colnerud, 
2015; Scott et al., 2014). For example, by investigating how students with different learning styles (i.e., individual vs. project) evaluate the fairness of teachers' assessment of classroom participation, Crosthwaite, Bailey, and Meeker (2015) discovered that students with individual learning styles regarded teachers' assessment of classroom participation as unfair because they were more inclined to working alone and valued classroom participation less than students with group and project learning styles. Moreover, they demonstrated that students with the individual learning style regressed in terms of class participation grades whereas students with group and project learning styles progressed. This study demonstrates that even the assessment method can 'pollute' students' scores and prevent them from demonstrating what they know. Building on these findings, avoid score pollution can have two dimensions: firstly, students' grades should exclude factors that are construct-irrelevant; secondly, the students' grade should exclude factors that underrepresent the construct related to their achievement.

\section{Group Work and Peer Assessment}

The studies reported so far provide an account of fairness themes for CA in general; however, there are additional studies that outline fairness themes for group work and peer assessment that have implications for CA fairness. Several themes were found as related to group work and peer assessment such as: (a) group composition (Webb, Nemer, Chizhik, \& Sugrue, 1998); (b) equity in grading (Barfield, 2003); (c) involvement in criteria development (Fellenz, 2006; Langan et al., 2005; Sivan, 2000; Tillema, Leenknecht, \& Segers, 2011); (d) gender bias (Falchikov \& Magin, 1997; Langan et al., 2005); (e) friendship bias (Magin, 2001; Panadero, Romero, \& Strijbos, 2013); and (f) cognitive bias (Gweon, Jun, Finger, \& Rosé, 2017).

Webb et al. (1998) have explored the effect of group composition on students' performance. They demonstrated that performance of below-average students improved greatly 
when they worked with above-average students while the group without above-average students performed weaker. Moreover, the group with only above-average students demonstrated better performance indicating that the above-average students were at a disadvantage when working with below-average students in a group. This finding suggests that group composition can affect the fairness of grades in group work.

Another study focused on students' fairness perception and satisfaction with respect to the grades they receive in groups. Barfield (2003) argues that students' grade expectancy, hours spent in a job outside the university, and age can affect their fairness perception and satisfaction. Barfield demonstrated that students who lacked previous experience of group work considered equal group grades as fair while experienced students regarded equitable distribution of grades as fair. He also found that students with a full-time job did not consider equal grades fair due to inequality of the inputs such as the time they allocated to the group work to the grade they received. Finally, Barfield reported that older students regarded group grades more unfair than younger students.

Several studies have also emphasized the positive impact of student voice and involvement in the development of criteria as a strategy to develop a fair peer assessment; for example practices of the co-development of learning goals or rubric criteria for assessment (Fellenz, 2006; Langan et al., 2005; Sivan, 2000; Tillema et al., 2011). Others have examined the effect of gender and friendship biases on the fairness of peer assessment. Although Falchikov and Magin (1997) did not identify gender bias in peer assessment, Langan et al. (2005) demonstrated that students of the same gender gave higher marks to each other. Concerning friendship bias, Panadero et al. (2013) found that a friendship effect was significant for one of the experimental groups, while Magin (2001) reported that friendship had very negligible impact. 
The last study focused on another type of bias, known as cognitive bias (Gweon et al., 2017). The authors examined if instructors were affected by cognitive biases such as a halo effect and fundamental attribution theory when assessing students' group work in a project-based learning course. Halo effect refers to a cognitive bias where people construe the traits of an individual in congruence with the traits that they have already observed from that individual. Fundamental attribution theory refers to a tendency to underestimate the impact of the specific contexts that led to a particular behavior or performance of an individual and instead attribute the behavior or performance to the individual's internal disposition. Building on their fivedimensional assessment rubric (i.e. goal-setting, progress, knowledge co-construction, participation, and teamwork), Gweon et al. (2017) compared the assessment of observers who directly observed group work sessions with the assessments made by the instructors who had little direct observation of group work sessions. They then examined the extent to which the assessment of instructors and direct observers were affected by the halo effect and fundamental attribution theory. They observed that the instructors gave similar scores across the five dimensions of rubric compared to the observers, which suggests that they might have generalized the good performance of a group in some of the dimensions to other dimensions that they had less opportunity to observe directly (i.e. the halo effect). Further, they discovered that the instructors tended to give an individual student a score very similar to his or her group score, which suggests that each student's score was greatly affected by their group score (i.e. the fundamental attribution theory).

The review of the studies on fairness in peer assessment provided additional information on how teachers can enact fair peer assessment practices, a common activity in CA contexts. However, as little scholarship exists on the conceptualization of fairness in peer assessment, 
future studies can look at conceptualizations of peer assessment beyond the assessment domain as practiced in education and related fields (such as the themes for fairness of peer assessment that will be reviewed in the non-assessment section) and draw on the theoretical framework of Fellenz (2006) for further advancement of fairness theory in peer assessment.

\section{Fairness in Non-assessment Domains}

Sex Bias

Sex bias can take place when a teacher's quality of interaction and assessment are affected by a student's gender. Two groups of studies have addressed sex bias. In the first group, the impact of sex bias was observed on the quality of teacher-student interaction. In the other group, the impact of sex bias was observed on the quality of teachers' assessment practices. Across these studies, sex is most typically defined as a binary construct (male vs. female), with future work needed related to gender biases that account for diverse gender constructions and identities.

Regarding the relationship between sex bias and teacher-student interaction, which is critical to formative assessment processes, Jones and Dindia (2004) in their meta-analytic review of 32 studies on sex bias concluded that teachers interacted more with males than females while males were criticized more and were given more negative feedback than females. Similarly, Duffy, Warren, and Walsh (2001) examined whether or not teachers' sex and school subject (i.e., mathematics and language) effected their behavior toward male and female students. They observed that female instructors tended to interact with males more than females and female mathematics and language teachers tended to interact more with males. Likewise, schoolchildren in England have reported that teachers are biased against boys more than girls (Myhill \& Jones, 2006). 
Although the above studies confirm the impact of sex bias on teacher-student interaction, Brady and Eisler (1999) identified no significant difference on college instructors' behavior towards male and female students. Similarly, after investigating whether teachers' questioning is effected by sex-biased behavior, students' voluntary rate, or students' achievement levels, Altermatt, Jovanovic, and Perry (1998) posited that teachers' disparate interaction in terms of the frequency and types of questions they direct to male and female students is due to students' differences in voluntary rate in answering questions (gender-role characteristics) as well as differences in their achievement levels.

Three studies have focused on the impact of sex bias on the quality of teachers' assessment. Two studies have examined the impact of sex bias on teachers' grading and reported that male and female students received different grades even for the identical performance on the assessment tasks (Newstead \& Dennis, 1990; Spear, 1984). Another study demonstrated that method of assessment can negatively disadvantage either male or female students' performance (Hazel, Logan, \& Gallagher, 1997). In this study, male students outperformed female students in terms of decontextualized multiple-choice items while the reverse was true for contextualized qualitative questions. Findings of these studies suggested that inattention to the impact of sex bias on students' assessment performance can negatively affect their opportunities to demonstrate learning and pollute their grades. Therefore, it is necessary to eliminate sex bias. In this regard, Sadker and Sadker (1986) suggested that "educators are generally unaware of the presence or the impact of this bias. Brief but focused training can reduce or eliminate sex bias from classroom interaction" (p. 512). Kelly (2002) recommended several strategies to enhance sex equity: (a) raising the awareness of teachers about sex-biased behaviors; (b) encouraging teachers to reflect on how the content of materials can affect sex-bias; (c) encouraging teachers 
to continue reading the current studies on sex equity; (d) emphasizing the role of preparation in reducing sex-biased behavior; and (e) prioritizing sex equity when teaching to students.

Although findings of the reviewed studies suggest differences on the extent and nature of sex bias in the classroom, it appears to be a consistent dimension of the classroom context with an influence on students' perceptions of fairness. Additional current and focused research is needed in this area to explore how teachers' sex-biases can pollute students' assessments and grades and their opportunity for and to demonstrate learning.

\section{Distributive Justice}

Distributive justice is regarded as one of the three dimensions of classroom fairness that considers the socially just distribution of both positive and negative outcomes (Chory-Assad, 2002; Chory-Assad \& Paulsel, 2004a). Equality, equity, and need are usually recognized as distributive justice principles (Colquitt, 2001). The principle of equality suggests that fairness is established when outcomes are distributed equally among students. Sussman (1975) explains how students perceive equity as (in)justice first by scrutinizing their own input (e.g., effort and time) in relation to their outcome (e.g., grade and recognition) and then by comparing their inputto-outcome ratio with the input-to-outcome ratio of similar others to see whether they are comparable. Comparable results lead to perception of justice whereas incomparable ones result in perception of injustice. Finally, the principle of need suggests that outcome distribution is fair if outcomes are distributed based on students' needs.

Research has revealed that students' conception of distributive justice change as they develop cognitively. Children at age 4 recognize equality as the building block of fairness; they distribute outcomes between themselves and others based on this principle, albeit they are usually unable to verbally articulate the reasons behind their fair distributions (Nikiforidou \& 
Pange, 2015). Some studies suggest that students' conceptions of fairness continues to be based on equality benchmark until age 17; afterwards, students also use principles of equity and need to judge the fairness of rewards and punishment (Berti, Molinari, \& Speltini, 2010; Evans, Salisbury, Palombaro, \& Goldberg, 1994; Sayre \& Ankney, 1976; Thorkildsen, 1989a, 1993, 1994a; Welch, 2000). Others have challenged this idea and argued that students' choice of distributive justice principles is not totally managed by their age, but depends on the particular contexts (Pnevmatikos \& Trikkaliotis, 2012; Thorkildsen, 1994b). For example, interviewing what practice students consider fair in teaching and testing conditions using scenario-based design, Thorkildsen (1989a, 1989b) found out that although children consider peer-tutoring (i.e., after finishing the task, fast learners help slow learners) as the fairest practice in learning contexts until age 17, they regarded it as unfair in testing contexts (i.e., after finishing the test, fast learners help slow learners) after age 11. This finding indicates that, in a learning context, students shape equity-based conception of fairness in late adolescence while in a testing context they achieve adult-like conception of fairness in the early adolescence (Thorkildsen, 1994a).

Other studies have focused on how students apply distributive justice principles. These studies have found that students apply distributive justice principles to judge the fairness of an outcome distribution in the following domains: grading, instructor affect, and punishment (Bempechat, Ronfard, Mirny, Li, \& Holloway, 2013; Ehrhardt, Pretsch, Herrmann, \& Schmitt, 2016; Horan, Chory, \& Goodboy, 2010; Whitley, Perkins, Balogh, Keith-Speigel, \& Wittig, 2000). As regards the principle of equity in grading, Resh (2009) reports that teachers and students unanimously believe that grades are fair when they include the following inputs and associated weights: performance (60\% teachers, $50 \%$ students), effort (both $19 \%$ ), and need ( $6 \%$ teachers, $14 \%$ students). In addition to these inputs, students believe that their actual grades 
should be congruent with their expected grades. Investigating the misalignment between students' actual and expected grade in relation to their perception of fairness through a scenariobased experiment and natural conditions, Cherry, Ordóñez, and Gilliland (2003) found that although students considered more-than-expected grades as unfair in the laboratory condition, they perceived them as fair in the real-life condition. However, less-than-expected grades were perceived unfair in both contexts (Cherry et al., 2003).

Unlike grading, students report that instructor affect (e.g., respect) should be predicated on the equality principle (Gorard, 2012). This communicates that students expect their teachers to respect everyone in the classroom. Nonetheless, similar to grading, they believe that allocation of punishment should be based on the equity principle. Two studies (Bear \& Fink, 1991; Reyna \& Weiner, 2001) suggest that teachers and students bear in mind several inputs such as reputation of a student (i.e., well-behaved or misbehaved), severity of the misbehavior (e.g., fighting or talking with peers), controllability (i.e., an action was within or out of student's control), and stability of the misbehavior (i.e., consistency in misbehaving) to construe the equity of punishment. In Bear and Fink's (1991) study, students showed that the suspension of a wellbehaved student due to disturbing a classroom (i.e., talking with a peer, getting out of their seat) was less fair than when a misbehaved student was involved. Nonetheless, suspension was considered fair when the misbehavior was severe (i.e., fighting). In Reyna and Weiner (2001), teachers considered punishment fair when the misbehavior was consistent and within the control of a student.

These studies suggest that students' conceptions of distributive justice are vastly complex. Although students consistently apply three distributive justice principles to evaluate the outcome distribution, the reviewed studies indicate that students' conceptions of distributive 
justice are altered based on their age and domain-specific conditions. Applied to classroom assessment, future research can shed light on how students across age groups perceive the fairness of equity, equality, and need in distributing opportunity to learn and demonstrate learning outcomes such as feedback, accommodations, and teacher and peer-directed questions.

\section{Procedural Justice}

Procedural justice emerged from the literature as another dimension of classroom fairness, which emphasizes the procedures of social justice leading to desired outcomes (ChoryAssad, 2002). Unlike distributive justice that focuses particularly on the outcome distribution, procedural justice considers the classroom procedures that give rise to particular classroom outcomes and distributions. The literature suggests several sub-themes form students' perception of procedural justice including student voice (Colquitt, 2001; Oppenheimer, 1989; Schmidt, Houston, Bettencourt, \& Boughton, 2003; Tata, 2005), promise-keeping (Horan et al., 2010), consistency (Colquitt, 2001; Robbins \& Jeffords, 2009), flexibility (Houston \& Bettencourt, 1999; Whalen \& Koernig, 2009), and accuracy, transparency, and explicitness of information (Gordon \& Fay, 2010; Grace, 2017; Pepper \& Pathak, 2008). Student voice highlights the importance of providing students with the opportunity to articulate their opinions and assume ownership over decision-making processes (including feedback and grading decisions) in the classroom. Examining student voice as an aspect of procedural fairness, Schmidt et al. (2003) explored students' perception of fairness using two scenarios: in one scenario, students were given the opportunity to appeal their grades, and in the other, they were deprived of the opportunity to appeal grade decisions. The authors found that respondents were more likely to perceive the assessments as fair when they were provided with the appeal option, even if they did not make use of it. Similarly, Oppenheimer (1989) examined whether or not providing students 
with the chance to grade the presentation of classmates can improve their perception of procedural fairness and found that students with the opportunity to grade the presentation of their classmates perceived more fairness than those without the opportunity. Tata (2005) compared American and Chinese students' perception of procedural fairness using scenarios that included student voice conditions. She found that Americans placed more value on having voice than Chinese students; thus, Americans felt fairer than Chinese students when they were provided with a voice while they felt more unfair than Chinese students when they were deprived of voice. This study underscores the role that culture plays in altering what students consider as (un)fair. More research is needed on students' perceptions of fairness in diverse socio-political and cultural contexts such as democratic and undemocratic, and individualistic and collectivist societies.

Promise-keeping was found in a qualitative study by Horan et al. (2010), which focused on American higher education students' perception of fairness. Promise-keeping involves teachers enforcing classroom procedures based on the previous promises and agreements with students. An example from Horan et al.'s study demonstrates the impact of promise-keeping on students' sense of fairness as articulated by a student:

During dead week one semester, my professor changed the date of the following week [sic]. The test was scheduled for Tuesday and the professor moved it to Thursday. When the class griped about how it was unfair, the professor said there would be no further discussion about the date of the exam (p. 462).

Consistency and flexibility are two sub-themes that appear contradictory in the literature as dimensions of classroom fairness. One the one hand, evidence suggests that students perceive the application of consistent practices to all students as fair (Robbins \& Jeffords, 2009); yet, on 
the other hand, they also see value in flexibility to accommodate special circumstances. In a qualitative exploration of the criteria that students consider for classroom fairness, Robbins and Jeffords (2009) found that 60 percent of students' responses focused on the significance of consistency in application of classroom procedures. In contrast, Whalen and Koernig (2009) noted students' desire for teacher flexibility in enforcing classroom procedures based on their special circumstances. Houston and Bettencourt (1999, p. 89) further document cases in which students advocate for flexible treatment; for instance, in the following case: "I got my wisdom teeth pulled this semester, and my instructor was fair enough to let me reschedule my speech that I had that week" (Houston \& Bettencourt, 1999, p. 89).

Finally, accuracy, transparency, and explicitness of information can help elucidate whether teachers' decisions for students are fair (Grace, 2017; Pepper \& Pathak, 2008). Pepper and Pathak (2008) gave two scenarios to students; in one scenario, the grading criteria were explicit and detailed and in the other, they were less explicit and not detailed. They found that students reported the scenarios with explicit and detailed grading criteria description as fair. Similarly, 89 percent of students in a qualitative exploration on what classroom procedures they perceive (un)fair reported that homework collection schedule should be notified earlier (Duplaga \& Astani, 2010).

Although we have described just one domain (e.g., grading) where each principles of procedural justice were applied, studies have demonstrated that students generally apply principles of procedural justice in domains such as attendance policy (Houston \& Bettencourt, 1999), course work load (Horan et al., 2010; Rodabaugh, 1994; Whitley et al., 2000), make-up policies (Horan et al., 2010), missed work policies (Houston \& Bettencourt, 1999), tests (Gordon \& Fay, 2010; Houston \& Bettencourt, 1999; Pepper \& Pathak, 2008), feedback provision 
(Whitley et al., 2000), and sanctions for cheating on an exam (Duplaga \& Astani, 2010). For example, Seevers, Rowe, and Skinner (2014) examined the transparency of feedback (i.e. public or private) and valence of feedback (positive or negative) on US students' perception of fairness. They found that positive feedback enhanced US students' perception of fairness while public feedback regardless of its positive and negative nature led to perceptions of unfairness as feedback in the US is typically given in private.

Although we have discussed procedural justice as a distinct dimension from distributive justice, the literature suggests that distributive and procedural justice interact to shape students' perception of fairness. For example, Tata (1999) investigated the association between distributive and procedural justice in shaping students' perception of fairness of grades and their subsequent evaluation of teaching effectiveness. She found that procedural justice neutralized the effect of distributive injustice on the formation of students' fairness conceptualizations. Therefore, students evaluated their distributive unjust teacher more favorably when treated procedurally fairly. This study suggests that if students perceive their outcomes as distributively unjust, they refer to the information related to procedural justness of an outcome distribution (Grace, 2017). Further, based on Chory, Horan, and Houser's (2017) work in which 54 percent of students' perceived unfairness related to their perceptions of procedural injustice compared to 29 percent for distributive and 14 percent for interactional justice, there is substantial evidence to suggest that procedural justice is key to supporting classroom fairness practices.

\section{Interactional Justice}

Interactional justice, relational equity, or relational justice are terms used in the literature to characterize the third dimension of classroom fairness. Unlike distributive and procedural justice which focus on the structural aspects of classroom fairness, interactional justice attends to 
the social dynamics and relational dimensions of fairness (Chory-Assad \& Paulsel, 2004b; Paulsel \& Chory-Assad, 2005). Interactional justice consists of two facets: interpersonal justice and informational justice. Interpersonal justice refers to the extent teacher-student and peer-topeer relationships are respectful; whereas informational justice refers to the extent teachers provide students with adequate, truthful, and justified information (Colquitt, 2001). Interpersonal and informational justice are viewed as significant aspects of classroom fairness because teachers are considered as moral agents in the classroom who can impart their (fairness) values (sub)consciously to students by means of a direct education or through indirect behavior (Boaler, 2008; Campbell, 1997; Chory-Assad, 2002; Chory, 2007; Whitley et al., 2000).

Researchers have identified interpersonal justice principles such as respect, caring, and power for teacher-student relationship (Bempechat et al., 2013; Buttner, 2004; Colnerud, 2006; Ehrhardt et al., 2016; Horan \& Myers, 2009; Houston \& Bettencourt, 1999; Kerssen-Griep \& Witt, 2012; Paulsel, Chory-Assad, \& Dunleavy, 2005; Whitley et al., 2000). Students perceive respect not only through verbal articulation, but from teachers' nonverbal acts. After examining the effects of teachers' nonverbal immediacy cues (i.e., the use of appropriate body language and vocal variety such as tone) and face threat mitigation tactics (i.e., any act to protect the selfimage of a person) on students' perception of fairness of instructional feedback, Kerssen-Griep and Witt (2012) concluded that these two acts were significantly linked with students' perception of interactional justice.

In addition, research has demonstrated that disrespect through verbal aggression (Claus, Chory, \& Malachowski, 2012), insensitive and rude behavior (Bempechat, et al., 2013; Buttner, 2004; Horan et al., 2010), sexual or ethnic humor (Torok, McMorris, \& Lin, 2004), sexist, racist, and prejudiced behavior, accusations of students, and implied or stated stupidity (Čiuladienė \& 
Račelytė, 2016; Horan et al., 2010; Israelashvili, 1997) is typically perceived as unfair by students. For example, $71 \%$ of Turkish students, in Tomul, Çelik, and Tas (2012) study, reported that their teachers discriminated against them based on their political affiliation, faith, economic background, or ethnicity. Moreover, half of the responses in Robbins and Jeffords' (2009) study, focused on the 'no favoritism' theme, which suggests the significance of respect and equal treatment for students' perception of fairness.

Teachers' concern, kindness, task-related help, and interest in students' learning are identified as associated with the caring principle that leads to students' perception of interpersonal justice (Buttner, 2004; Colnerud, 2006); however, lack of affective character and kindness (Buttner, 2004; Chory, 2007; Horan et al., 2010; Lankiewicz, 2014; Murdock, Miller, \& Goetzinger, 2007), failure to know students' names (Buttner, 2004), failure to answer students questions effectively or interact enjoyably with them (Young, Horan, \& Frisby, 2013), and failure to provide students with task-related help (Buttner, 2004) have been reported as indicators of uncaring relationship that potentially leads to students' perceptions of unfairness.

Teachers' use of power can also contribute to students' perception of (un)fairness. Investigating the relationship between power and classroom fairness, Paulsel et al. (2005) found that students considered teachers who used coercive power (i.e., implying that students will get punished if they refuse to obey the teacher) as unfair whereas they perceived teachers who used expert power (i.e., suggesting that teachers' power exertion is justified because s/he is the most knowledgeable in the classroom), referent power (i.e., implying that teacher is an authority with whom students are willing to get identified), and legitimate power (i.e., implying that teacher as an authority in the class has the right to decide and implement decisions) as fair. What appears interesting about power is that students' perception of fairness due to appropriate exertion of 
teacher power can contribute to their empowerment while power exerted inappropriately leads to a sense of powerlessness (Israelashvili, 1997).

Although the above principles generally focus on the fairness of teacher-student relationship, peer bias is related to both fairness of teacher-student relationship and peer-to-peer relationship. Peer bias is a bias that is directed to a classmate by peers, and is usually in the form of stereotypes, offensive jokes, avoidance or isolation, slurs, and insults. Boysen and his colleagues carried out a series of studies to investigate the extent to which students and teachers experience peer bias in the classrooms and how teachers effectively react against it (Boysen, 2012; Boysen \& Vogel, 2009; Boysen, Vogel, Cope, \& Hubbard, 2009). Two of the studies demonstrated that a quarter of instructors and half of the students had the experience of peer bias (Boysen \& Vogel, 2009; Boysen, Vogel, Cope, \& Hubbard, 2009). In another study, Boysen (2012) found that instructors reacted against peer bias regularly in the forms of direct confrontation, discussion, and ignorance, and less commonly in the form of private confrontation, and provision of counterexamples. Furthermore, students reported direct confrontation followed by discussion as the most effective reaction to prevent future occurrence of peer bias in classroom.

Informational justice is the second facet of interactional justice and includes the following sub-themes: adequacy, truthfulness, and justification (Buttner, 2004; Oppenheimer, 1989; Schmidt et al., 2003; Whitley et al., 2000). To explore factors that contribute to students' informational (un)fairness, Buttner (2004) identified teachers' recognition (i.e., careful listening to students' ideas), responsiveness (i.e., answering students questions, emails, etc.), nondefensiveness (i.e., welcoming challenges by students), and class integrity (i.e., being honest and truthful) as leading to students' perception of fairness. Moreover, Oppenheimer (1989) and 
Schmidt et al. (2003) found that students perceived teachers who justified their grading decisions using adequate and truthful information as fair. Further, Buttner (2004) identified teachers' defensiveness (i.e., refusing challenges by students), lack of honesty, and lack of attention to students' ideas as leading to students' perception of unfairness.

A recent distinction has been made between two forms of informational justice that is illuminating for further research. Kazemi (2016) makes an interesting distinction between proactive and reactive informational justice. He argues that, in the proactive form, informational justice can work independently from other justice dimensions and contribute directly to students' perception of (un)fairness. For example, teachers' adequate and justified communication of grading criteria at the beginning of a semester can itself directly contribute to students' perception of fairness. However, reactive information can be used as a means to reduce the perception of unfairness caused by other dimensions. For instance, teachers' careful listening to students' appeals for grades and adequate justification of why they deserved the grades they got can lessen the perception of unfairness in a student as related to distributive justice.

The 4 studies above were the only studies among 133 that dealt with informational justice; therefore, it appears that relatively less attention has been paid to informational justice compared to interpersonal justice or other justice dimensions (i.e., distributive and procedural).

\section{Pedagogy}

Teachers' pedagogy is another dimension of fairness highlighted across several studies (Bempechat et al., 2013; Resh \& Sabbagh, 2016; Sabbagh \& Resh, 2016; Sabbagh, Resh, Mor, \& Vanhuysse, 2006). A number of studies (Bempechat et al., 2013; Chory, 2007; Lankiewicz, 2014; Murdock, Beauchamp, \& Hinton, 2008; Rodabaugh, 1994) identified lack of pedagogical knowledge and competence as a prevalent theme in accounting for students' perception of 
unfairness. Deficiency in pedagogical knowledge can lead to teachers' failure to explain and communicate the content adequately, which can in turn affect students' opportunity to learn, grades, and feedback negatively. In this respect, one of the students, in Bempechat et al's (2013) qualitative study of perceptions of fairness demonstrated how teachers' failure to communicate the content could affect their grades negatively: "Our chemistry teacher, he is so weird! He never explains anything. He asks us questions we can never answer and almost everyone gets 2 [a poor grade]" (p. 176). Further, 300 college students in a qualitative study reported that teachers' lack of pedagogical knowledge is the second most severe unfair behavior in higher education contexts (Rodabaugh, 1994).

Research has also identified failure to explain the coursework in detail, failure to allocate time to address students' confusions, and rushing through lessons as factors that contribute to students' perception of unfairness (Bempechat et al., 2013; Rodabaugh, 1994). For example, one of the students in Bempechat et al's (2013) study reported the following case as an instance of rushing through lessons and failure to address students' confusions. "Our chemistry teacher briefly explains us new material and then we have a test on the next lesson. And I am not that kind of person who can understand the material quickly, I need a detailed explanation” (p. 177). Finally, Bempechat et al. (2013) found that failure to maintain classroom discipline could contributing to students' perception of unfairness. The following example represents one of the students' comments with respect to this sub-theme:

Well, I think the matter is in the teacher; she can't really calm kids down. Like if the teacher was strict from the very beginning, kids wouldn't mess around on his lessons. Very often kids disrupt lessons because of something insignificant and the teacher gets 
angry. Sometimes teachers disrupt lessons themselves, like they start yelling at us because of something and do it till the end of the lesson (Bempechat et al., 2013, p. 177). Resh and Sabbagh (2016) have argued in their review of the literature of classroom fairness that little scholarship has focused on identifying fairness principles for the pedagogy dimension. Based on our review here, we would concur. Additional research is required to identify pedagogical practices that are perceived (un)fair by both teachers and students, and to examine how unfair pedagogies can be mitigated through distributive, procedural, interpersonal and informational justice principles.

\section{Students' Fairness-related Beliefs}

Students' fairness-related beliefs (i.e., factors that indirectly alter students' perception of fairness derived by application of fairness principles) work closely with other fairness dimensions to shape students' experiences of fairness. Three sub-themes were found as related to students' beliefs about fairness: belief in a just world, beliefs about the meaning of learning, and locus of control (Duplaga \& Astani, 2010; Peter \& Dalbert, 2010; Thorkildsen, Nolen, \& Fournier, 1994). Extensive research has been conducted into belief in a just world, connecting students' belief systems to fairness perceptions (Alt, 2015; Alt \& Itzkovich, 2015; Donat, Dalbert, \& Kamble, 2014; Human-Vogel \& Morkel, 2017; Peter \& Dalbert, 2010; Peter, Dalbert, Kloeckner, \& Radant, 2013; Peter, Kloeckner, Dalbert, \& Radant, 2012). Belief in a just world is a construct with two facets; the first one is personal belief in a just world that considers the extent individuals construe their life events as fair; the second one is general belief in a just world that refers to the extent individuals believe that the world is a fair place. Peter and Dalbert (2010) examined the effect of personal belief in a just world on classroom climate while mediated by teachers' just behavior; they discovered that students who had strong personal belief 
in a just world perceived teacher behavior and classroom climate fairer than students who had a weaker personal belief in a just world. Similarly, Alt (2015), using structural equation modeling, demonstrated that personal belief in a just world predicted teachers' just behavior and teacher just behavior predicted students' perception of learning environment. Therefore, students who perceived their teachers' behavior toward them as personally just evaluated their learning environment as more positive. Although the above two studies considered the predictive effect of belief in a just world on students' perception of fairness, Berti, Mameli, Speltini, and Molinari (2016) examined the predictive effect of students' perception of teacher justice on students' belief-in-a-just-world and their motivation. They discovered that students' perception of teacher justice predicted their belief-in-a-just-world $(\beta=.42)$ and motivation $(\beta=.33)$ significantly.

Students' beliefs about the meaning of learning can affect their perception of fairness in teachers' pedagogical practices. Interviewing schoolchildren about how they perceive the fairness of certain pedagogical practices, Thorkildsen et al. (1994) have found that schoolchildren perceive meaningful and effortful learning that recognizes their devotion and effort, involves their intrinsic motivation, and fits with their interests as fair; however, they view learning due to extrinsic rewards as the least fair (Thorkildsen et al., 1994). Furthermore, examining what pedagogical practices are perceived fair in enhancing learning, Thorkildsen (1989a) found that slow and fast learners unanimously asserted that 'peer-tutoring' (i.e., after finishing the task, fast learners help slow learners) was the fairest practice. However, they reported that 'enrichment' (i.e., after finishing the first task, fast learners enrich their learning with activities other than their lesson) was the most frequent practice in their classrooms, which indicates the mismatch between what students perceive as a fair pedagogical practice and what is actually practiced. 
Finally, locus of control was identified as a theme that can alter students' perception of fairness (Duplaga \& Astani, 2010). Locus of control is defined as the extent individuals perceive that they can exercise control over events in their lives. Although locus of control is not a dichotomous concept (i.e., internal vs. external), individuals can be generally identified as internally or externally oriented in terms of locus of control. Individuals with internal locus of control believe that life events are within their control and accept responsibility to what happens for them. In contrast, individuals with external locus of control resort to external factors such as bad luck to state that life events were out of their control. In this respect, Duplaga and Astani (2010) examined the relationship between students' locus of control and their fairness perceptions of classroom procedures. As an illustration of the effect of locus of control on students' perception of fair sanction policy for cheating on a quiz, they demonstrated that students with external locus of control perceived the procedure of zero score for the first-time cheating on a quiz, and a failing score for the entire course for the second occurrence of cheating as fair for 73 percent vis-à-vis 59.8 percent reported by internally oriented students.

\section{Group Work and Peer Assessment}

Compared to the general focus of previous studies on classroom fairness, the following three studies were found to focus on group work and peer assessment. In the first study, Davison, Mishra, Bing, and Frink (2014) examined how students' ability (i.e., high vs. low) can affect their application of distributive justice principles in assessing their peers' group work. They found that high ability students applied the equity principle (i.e. their contributions to the grade ratio) to give grades to their peers while low-ability students used the equality principle (i.e. equal grades). The reasons for such a distinction were lack of awareness of what constituted a good work by low-ability students and high ability students' inclination to give lower scores to 
low ability students to compensate for the weak practice of low-ability students (Davison et al., 2014).

In the second study, Carvalho (2013) examined students' experience of peer assessment in a problem-based learning course. She found that, in general, $70 \%$ of students reported positive experience in terms of peer assessment while almost $42 \%$ of the students perceived peer assessment exercise as unfair and 39\% regarded the final mark from peer assessments as unfair.

In the third study, building on the three dimensions of distributive, procedural, and interactional justice in organizational justice theory, Hannay (2014) proposed a framework for fairness in peer assessment. To establish a fair peer assessment, she suggested that (a) grades should be distributed among peers based on an equity principle (distributive justice principle); (b) peers should receive detailed feedback and have the opportunity to appeal for their grades from their teachers and classmates (procedural justice principles); and (c) peers should receive respectful, detailed, and adequate feedback on why they got a particular grade (interactional justice principles). We would suggest that future research can build on organizational justice theory and its dimensions, as adopted by Hannay (2014), to frame the theory of fairness in peer assessment.

\section{Instructional Accommodation}

Instructional accommodations are changes in the way instruction is presented and the way a student takes part in classroom activities (such as homework, small-group and class-wide instructions) often in response to student-specific learning needs (e.g., students with individual education plans). Importantly, instructional accommodations do not modify the curriculum expectations or standards for students, rather only change instruction, environment, and opportunities to learn and demonstrate learning. Baker and Scanlon (2016) argue that 
instructional accommodations prove effective when (a) students are aware of the range of instructional accommodations available to them, (b) their perspectives of how they have experienced accommodations in the classrooms are accounted for, and (c) students can assume agency in the process and enactment of their instructional accommodations rather than teachers taking the entire responsibility. In order to explore students' awareness, experiences, and agency in their instructional accommodations, Baker and Scanlon (2016) conducted focus group interviews with high-incidence disability (HI) students. Through their study, they found that these students often lacked awareness of the general processes based on which schools identify accommodations. Further, eight students out of ten, who were participants for this study, reported that they had little or no knowledge of their accommodations. Nonetheless, students reported that they assumed agency in their accommodation process by signaling their needs for accommodations during the classroom using several strategies, such as pulling the teacher.

Along with these findings, students in Baker and Scanlon's (2016) study repeatedly alluded to the role of affect and fairness in the effectiveness of instructional accommodations. Most of the HI students expressed experiences of negative feelings of embarrassment, weirdness, and awkwardness when receiving accommodations among peers, which created barriers for them in using accommodations effectively. Further, they had concerns about the fairness of the distribution of instructional accommodations based on either need or equality principles. Some students believed that they should receive accommodations based on their needs whereas others maintained that accommodations should be distributed equally: "the written instructions would be given to "all the kids"” and "It would be like basically changing the whole class for just a few kids" (Baker \& Scanlon, 2016, p. 101). It appears that students struggle between equality and equity principles as related to fairness conceptions at this developmental stage; students tend to 
value and understand equality until approximately age 17 over equity (Thorkildsen, 1989a, 1994a). Given the emerging findings related to fairness and instructional accommodations, there is a need to further investigate how instructional accommodations yield experiences of fairness in classrooms and assessment, with considerations for the theoretical and philosophical foundations driving accommodated assessment practices.

\section{Discussion}

Fairness is deemed a key component of CA theory and practice (Tierney, 2013) and a major component in teacher assessment literacy models (DeLuca et al., 2016). The persistent emphasis on fairness has led to the continued emergence of studies attempting to (re)frame fairness in CA (Green et al., 2007; Johnson et al., 2008; Liu et al., 2016; Pope et al., 2009; Tierney, 2014). Despite the concerted efforts to study fairness, most of these studies have looked at previous theories of fairness from within the assessment domain. Tierney (2014) calls for additional conceptualizations of CA fairness by drawing on how fairness has been theorized in other fields. Therefore, in this systematic review, we comprehensively analyzed 150 studies in both assessment and non-assessment education domains to conceptualize fairness for CA.

The emergent themes from our review of the assessment oriented studies suggest that fairness has been conceptualized in relation to summative (i.e., graded) and formative assessment practices. In the summative view, fairness has typically been characterized as including principles that transpire before, during, and after assessment administration, and comprise issues such as equal access to opportunity for learning, clear and consistent grading criteria, avoidance of score pollution, and accommodation based on students' ability and linguistic backgrounds (Abedi et al., 2004; Aitken, 2012; Camilli, 2006, 2013; Gipps, 1995; Gipps \& Stobart, 2009; Klenowski, 2014; Scott et al., 2014; Suskie, 2000; Volante, 2006). 
Recent scholarship on fairness for formative assessment takes into account additional factors that have been shown to have a bearing on learning. These factors include constructive, respectful, and caring environment, transparent, consistent and justified communication of information and feedback, equity in terms of the equal access of all students to the benefits of formative assessment, and teachers' reflective thinking and practice of fairness (Cowie, 2015; Lizzio \& Wilson, 2008; Tierney, 2014).

While there is some beginning work being done on how fairness principles interact with formative assessment practices in classrooms, this remains an area for further research. We see this area as particularly fertile for 'reconceptualizing' (Tierney, 2014) fairness for CA contexts.

Based on our systematic review, we are able to contribute toward the conceptualization of CA fairness by considering literature beyond the assessment field. Specifically, our review of 100 articles on classroom fairness revealed eight key themes that characterize fairness: sex bias, distributive justice, procedural justice, interactional justice, pedagogy, students' fairness-related beliefs, group work and peer assessment, and instructional accommodation. In Figure 1, we organize these themes into three elements of classroom practice, which have been identified by Cowie and Bell (1999) as the core dynamic elements shaping classroom assessment theory: teaching, learning, and classroom interactions. Our argument is that these various themes not only relate to these three core elements, but also have a direct influence on conceptualizations and practices of classroom assessment fairness.

\section{INSERT FIGURE 1 HERE}

Previous qualitative studies on students' perception of fairness have also demonstrated that students conceptualize fairness related to the classroom elements of teaching, assessment, learning, and classroom interactions (Bempechat et al., 2013; Buttner, 2004; Chory, Horan, \& Houser, 2017; Čiuladienė \& Račelytè, 2016; Horan et al., 2010; Houston \& Bettencourt, 1999; 
Israelashvili, 1997; Robbins \& Jeffords, 2009). These studies reveal that students' overall perception of fairness is shaped by individual contribution and interplay of these dimensions. Moreover, students' experiences of (un)fair assessment practices is shaped by their broader view of classroom fairness; hence, for students, there is an interaction between general classroom fairness and assessment fairness. This finding suggests that focus on assessment per se as the sole dimension of fairness might underrepresent students' conceptions and experiences of fairness. We suggest that CA can incorporate a more comprehensive conception of fairness to enhance the learning experiences of students and create more positive conditions of fairness. In this respect, Peter and Dalbert (2010) argues that educational practice and also research should not only focus on principles and criteria for just behavior per se but also on the subjective meaning of these principles and criteria for the individual student. Otherwise it is difficult to say, if particular behavioral strategies recommended by educational sciences are indeed seen as just and thus have beneficial consequences for the students (p. 304).

Along with students, teachers' fairness mindset is framed by an interplay of the elements of teaching, learning, assessment, and classroom interactions (Horan \& Myers, 2009). In an era of assessment literacy, which includes fairness literacy as a significant dimension, teachers should be provided with a well-rounded body of knowledge of a multi-dimensional view of fairness in order to understand the interaction between general classroom fairness and assessment fairness. As an illustration, in spite of the principle of avoiding score pollution, teachers consider caring, future consequences of a grade for a student, effort, and desire to teach life lessons (Tierney, 2015) as fair factors in a grade alteration, which might be at odds with the current conception that only examines fairness within an assessment focus. Therefore, we argue that the 
CA fairness construct should be considered in relation to the elements of teaching, learning, and classroom interactions and reflective of themes from both assessment and non-assessment fairness domains within each of these elements. In this way, we heed to our initial conceptualization of CA as a "broad and evolving" process (McMillan, 2013, p. 4) arguing that CA fairness should evolve to respond to the current CA theory, inclusive of formative processes, and in recognition of developments of fairness theory in non-assessment domains.

Future research in this area can explore teachers and students' conceptions of fairness in relation to teaching, learning, classroom interactions, and assessment elements. As it is necessary to interpret CA fairness findings through a particular fairness theory, it is beneficial to also theorize fairness as a multidimensional construct that interacts with these four classroom elements using empirical datasets drawn from across contexts. While our data for this study involved three rounds of systematic literature searches, we recognize that there are additional databases and studies that might be of value in the construction of this conceptualization of CA fairness. Accordingly, we present our systematic review as an initial step in re-conceptualizing fairness by drawing on literature beyond the assessment field. We welcome additions and revisions to this conceptualization as the basis for future research. 


\section{References}

References marked with the symbol (*) were found in the systematic search, and references marked with (\#) were found in the iterative searches.

*Abdelzadeh, A., Zetterberg, P., \& Ekman, J. (2015). Procedural fairness and political trust among young people: Evidence from a panel study on Swedish high school students. Acta Politica, 50, 253-278. doi:10.1057/ap.2014.22

*Abedi, J., Hofstetter, C. H., \& Lord, C. (2004). Assessment accommodations for English language learners: Implications for policy-based empirical research. Review of Educational Research, 74, 1-28. doi:10.3102/00346543074001001

\#Aitken, N. (2012). Student voice in fair assessment practice. In C. F. Webber \& J. Lupart (Eds.), Leading Student Assessment (pp. 175-200). Dordrecht: Springer.

\#Alm, F., \& Colnerud, G. (2015). Teachers' Experiences of Unfair Grading. Educational Assessment, 20, 132-150. doi:10.1080/10627197.2015.1028620

\#Alt, D. (2015). Using structural equation modeling and multidimensional scaling to assess students' perceptions of the learning environment and justice experiences. International Journal of Educational Research, 69, 38-49. doi:10.1016/j.ijer.2014.10.001

\#Alt, D., \& Itzkovich, Y. (2015). Assessing the connection between students' justice experience and perceptions of faculty incivility in higher education. Journal of Academic Ethics, 13, 121-134. doi:10.1007/s10805-015-9232-8

*Altermatt, E. R., Jovanovic, J., \& Perry, M. (1998). Bias or responsivity? Sex and achievementlevel effects on teachers' classroom questioning practices. Journal of Educational Psychology, 90, 516. doi:10.1037/0022-0663.90.3.516

Assessment Reform Group (2002). Assessment for learning: 10 principles. Retrieved November 
2012 from

http://assessmentreformgroup.files.wordpress.com/2012/01/10principles_english.pdf. Cambridge, UK: University of Cambridge. School of Education.

\#Baker, D., \& Scanlon, D. (2016). Student Perspectives on Academic Accommodations. Exceptionality, 24, 93-108. doi:10.1080/09362835.2015.1064411

*Barfield, R. (2003). Students' perceptions of and satisfaction with group grades and the group experience in the college classroom. Assessment \& Evaluation in Higher Education, 28, 355-370. doi:10.1080/0260293032000066191

*Bear, G. G., \& Fink, A. (1991). Judgments of fairness and predicted effectiveness of classroom discipline: Influence of problem severity and reputation. School Psychology Quarterly, 6, 83. doi:10.1037/h0088810

*Bempechat, J., Ronfard, S., Mirny, A., Li, J., \& Holloway, S. D. (2013). “She always gives grades lower than one deserves:" a qualitative study of Russian adolescents' perceptions of fairness in the classroom Journal of Ethnographic \& Qualitative Research, 7, 169-187.

\#Berti, C., Mameli, C., Speltini, G., \& Molinari, L. (2016). Teacher justice and parent support as predictors of learning motivation and visions of a just world. Issues in Educational Research, 26, 543-560.

*Berti, C., Molinari, L., \& Speltini, G. (2010). Classroom justice and psychological engagement: Students' and teachers' representations. Social Psychology of Education, 13, 541-556. doi:10.1007/s11218-010-9128-9

*Boaler, J. (2008). Promoting 'relational equity'and high mathematics achievement through an innovative mixed-ability approach. British educational research journal, 34, 167-194. doi:10.1080/01411920701532145 
*Boysen, G. (2012). Teachers' responses to bias in the classroom: How response type and situational factors affect student perceptions. Journal of Applied Social Psychology, 42, 506-534. doi:10.1111/j.1559-1816.2011.00784.X

*Boysen, G., \& Vogel, D. (2009). Bias in the classroom: Types, frequencies, and responses. Teaching of Psychology, 36, 12-17. doi:10.1080/00986280802529038

*Boysen, G., Vogel, D. L., Cope, M. A., \& Hubbard, A. (2009). Incidents of Bias in College Classrooms: Instructor and Student Perceptions. Journal of Diversity in Higher Education, 2, 219-231. doi:10.1037/a0017538

*Brady, K., \& Eisler, R. (1999). Sex and gender in the college classroom: A quantitative analysis of faculty-student interactions and perceptions. Journal of Educational Psychology, 91, 127-145. doi:10.1037/0022-0663.91.1.127

Brookhart, S. M. (2003). Developing measurement theory for classroom assessment purposes and uses. Educational Measurement: Issues and Practice, 22, 5-12. doi:10.1111/j.17453992.2003.tb00139.x

*Buttner, E. H. (2004). How Do We "Dis” Students?: A Model of (Dis)Respectful Business Instructor Behavior. Journal of Management Education, 28, 319-334. doi:10.1177/1052562903252656

*Camilli, G. (2006). Test fairness. In R. Brennan (Ed.), Educational measurement (4 ed., pp. 221-256). Westport, CT: American Council on Education and Praeger.

*Camilli, G. (2013). Ongoing issues in test fairness. Educational Research and Evaluation, 19, 104-120. doi:10.1080/13803611.2013.767602

*Campbell, E. (1997). Connecting the ethics of teaching and moral education. Journal of Teacher Education, 48, 255-263. doi:10.1177/0022487197048004003 
*Carless, D. (2006). Differing perceptions in the feedback process. Studies in Higher Education, 31, 219-233. doi:10.1080/03075070600572132

\#Carvalho, A. (2013). Students' perceptions of fairness in peer assessment: evidence from a problem-based learning course. Teaching in Higher Education, 18, 491-505. doi:10.1080/13562517.2012.753051

*Cherry, B., Ordóñez, L., \& Gilliland, S. W. (2003). Grade expectations: The effects of expectations on fairness and satisfaction perceptions. Journal of Behavioral Decision Making, 16, 375-395. doi:10.1002/bdm.452

*Chory-Assad, R. (2002). Classroom justice: Perceptions of fairness as a predictor of student motivation, learning, and aggression. Communication Quarterly, 50, 58-77. doi:10.1080/01463370209385646

*Chory-Assad, R., \& Paulsel, M. (2004b). Antisocial classroom communication: Instructor influence and interactional justice as predictors of student aggression. Communication Quarterly, 52, 98-114. doi:10.1080/01463370409370184

*Chory-Assad, R., \& Paulsel, M. L. (2004a). Classroom justice: Student aggression and resistance as reactions to perceived unfairness. Communication Education, 53, 253-273. doi:10.1080/0363452042000265189

*Chory, R. (2007). Enhancing student perceptions of fairness: The relationship between instructor credibility and classroom justice. Communication Education, 56, 89-105. doi:10.1080/03634520600994300

\#Chory, R., Horan, S. M., \& Houser, M. L. (2017). Justice in the Higher Education Classroom: Students' Perceptions of Unfairness and Responses to Instructors. Innovative Higher Education, 1-16. doi:10.1007/s10755-017-9388-9 
\#Čiuladienè, G., \& Račelytè, D. (2016). Perceived unfairness in teacher-student conflict situations: students' point of view. Polish Journal of Applied Psychology, 14, 49-66. doi:10.1515/pjap-2015-0049

*Claus, C., Chory, R., \& Malachowski, C. C. (2012). Student antisocial compliance-gaining as a function of instructor aggressive communication and classroom justice. Communication Education, 61, 17-43. doi:10.1080/03634523.2011.619270

*Colnerud, G. (2006). Teacher ethics as a research problem: Syntheses achieved and new issues. Teachers and Teaching: theory and practice, 12, 365-385. doi:10.1080/13450600500467704

*Colquitt, J. A. (2001). On the dimensionality of organizational justice: a construct validation of a measure. Journal of Applied Psychology, 86, 386-400. doi:10.1037/0021-9010.86.3.386

*Cowie, B. (2015). Equity, ethics and engagement: Principles for quality formative assessment in primary science classrooms. In C. Milne, K. Tobin \& D. DeGennaro (Eds.), Sociocultural Studies and Implications for Science Education (pp. 117-133). Netherlands: Springer

Cowie, B., \& Bell, B. (1999). A model of formative assessment in science education. Assessment in Education: Principles, Policy \& Practice, 6, 101-116. doi:10.1080/09695949993026

*Cronen, V. E., \& Fuller, R. (1976). Freshman perceptions of instructor fairness and expertise: A problem in course evaluation. Communication Quarterly, 24, 45-47. doi:10.1080/01463377609369209

*Crosthwaite, P., Bailey, D., \& Meeker, A. (2015). Assessing in-class participation for EFL: considerations of effectiveness and fairness for different learning styles. Language Testing in Asia, 5, 1-19. doi:10.1186/s40468-015-0017-1 
*Davison, H. K., Mishra, V., Bing, M. N., \& Frink, D. D. (2014). How individual performance affects variability of peer evaluations in classroom teams: A distributive justice perspective. Journal of Management Education, 38, 43-85.

doi:10.1177/1052562912475286

DeLuca, C. (2012). Preparing teachers for the age of accountability: Toward a framework for assessment education. Action in teacher education, 34, 576-591.

doi:10.1080/01626620.2012.730347

DeLuca, C., LaPointe-McEwan, D., \& Luhanga, U. (2016). Teacher assessment literacy: a review of international standards and measures. Educational Assessment, Evaluation and Accountability, 1-22. doi:10.1007/s11092-015-9233-6

\#Donat, M., Dalbert, C., \& Kamble, S. V. (2014). Adolescents' cheating and delinquent behavior from a justice-psychological perspective: the role of teacher justice. European Journal of Psychology of Education, 29, 635-651. doi:10.1007/s10212-014-0218-5

Downing, S. M., \& Haladyna, T. M. (2004). Validity threats: overcoming interference with proposed interpretations of assessment data. Medical Education, 38(3), 327-333. doi:10.1046/j.1365-2923.2004.01777.x

\#Duffield, K., \& Spencer, J. (2002). A survey of medical students' views about the purposes and fairness of assessment. Medical Education, 36, 879-886. doi:10.1046/j.13652923.2002.01291.x

*Duffy, J., Warren, K., \& Walsh, M. (2001). Classroom Interactions: Gender of Teacher, Gender of Student, and Classroom Subject. Sex Roles, 45, 579-593. doi:10.1023/A:1014892408105 
\#Duplaga, E. A., \& Astani, M. (2010). An exploratory study of student perceptions of which classroom policies are fairest. Decision Sciences Journal of Innovative Education, 8, 933. doi:10.1111/j.1540-4609.2009.00241.x

\#Ehrhardt, N., Pretsch, J., Herrmann, I., \& Schmitt, M. (2016). Observing justice in the primary school classroom. Zeitschrift für Erziehungswissenschaft, 19, 157-190. doi:10.1007/s11618-015-0664-0

*Evans, I. M., Salisbury, C., Palombaro, M., \& Goldberg, J. S. (1994). Children's perception of fairness in classroom and interpersonal situations involving peers with severe disabilities. Journal of the Association for Persons with Severe Handicaps, 19, 326-332. doi:10.1177/154079699401900408

*Falchikov, N., \& Magin, D. (1997). Detecting gender bias in peer marking of students' group process work. Assessment \& Evaluation in Higher Education, 22, 385-396. doi:10.1080/0260293970220403

*Fellenz, M. (2006). Toward fairness in assessing student groupwork: A protocol for peer evaluation of individual contributions. Journal of Management Education, 30, 570-591. doi:10.1177/1052562906286713

*Flores, M. A., Veiga Simão, A. M., Barros, A., \& Pereira, D. (2015). Perceptions of effectiveness, fairness and feedback of assessment methods: a study in higher education. Studies in Higher Education, 40, 1523-1534. doi:10.1080/03075079.2014.881348

*Gipps, C. (1995). What do we mean by equity in relation to assessment? Assessment in Education: Principles, Policy \& Practice, 2, 271-281. doi:10.1080/0969595950020303

*Gipps, C., \& Stobart, G. (2009). Fairness in assessment. In C. W.-S. J. Cumming (Ed.), Educational Assessment in the 21st century (pp. 105-118). London: Springer. 
*Gorard, S. (2012). Experiencing fairness at school: An international study. International Journal of Educational Research, 53, 127-137. doi:10.1016/j.ijer.2012.03.003

*Gordon, M., \& Fay, C. (2010). The effects of grading and teaching practices on students' perceptions of grading fairness. College Teaching, 58, 93-98. doi:10.1080/87567550903418586

\#Gotlieb, J. (2009). Justice in the classroom and students' evaluations of marketing professors' teaching effectiveness: An extension of prior research using attribution theory. Marketing Education Review, 19, 1-14. doi:10.1080/10528008.2009.11489069

\#Gouveia-Pereira, M., Vala, J., Palmonari, A., \& Rubini, M. (2003). School experience, relational justice and legitimation of institutional. European Journal of Psychology of Education, 18, 309. doi:10.1007/BF03173251

\#Grace, C. C. (2017). Exploring the potential for and promise of incorporating distributive and procedural justices into post-secondary assessment of student learning. Teaching in Higher Education, 22, 304-317. doi:10.1080/13562517.2016.1248388

*Green, S., Johnson, R., Kim, D., \& Pope, N. (2007). Ethics in classroom assessment practices: Issues and attitudes. Teaching and teacher education, 23, 999-1011. doi:10.1016/j.tate.2006.04.042

\#Gweon, G., Jun, S., Finger, S., \& Rosé, C. P. (2017). Towards effective group work assessment: even what you don't see can bias you. International Journal of Technology and Design Education, 27(1), 165-180. doi: 10.1007/s10798-015-9332-1

*Hannay, M. (2014). Fairness in peer evaluations: Ensuring organizational justice in the classroom. Journal of Higher Education Theory and Practice, 14, 61-68. 
*Hazel, E., Logan, P., \& Gallagher, P. (1997). Equitable assessment of students in physics: Importance of gender and language background. International Journal of Science Education, 19, 381-392. doi:10.1080/0950069970190402

*Holmgren, J., \& Bolkan, S. (2014). Instructor responses to rhetorical dissent: Student perceptions of justice and classroom outcomes. Communication Education, 63, 17-40. doi:10.1080/03634523.2013.833644

*Horan, S. M., Chory, R., \& Goodboy, A. (2010). Understanding students' classroom justice experiences and responses. Communication Education, 59, 453-474.

doi:10.1080/03634523.2010.487282

*Horan, S. M., Chory, R. M., Carton, S. T., Miller, E., \& Raposo, P. C. (2013). Testing leadermember exchange theory as a lens to understand students' classroom justice perceptions and antisocial communication. Communication Quarterly, 61, 497-518. doi:10.1080/01463373.2013.799511

*Horan, S. M., \& Myers, S. (2009). An exploration of college instructors' use of classroom justice, power, and behavior alteration techniques. Communication Education, 58, 483496. doi:10.1080/03634520903055981

*Houston, M., \& Bettencourt, L. (1999). But that's not fair! An exploratory study of student perceptions of instructor fairness. Journal of Marketing Education, 21, 84-96. doi:10.1177/0273475399212002

\#Human-Vogel, S., \& Morkel, J. (2017). Teacher and learners' belief in a just world and perspectives of discipline of Grade 4-8 learners in South African schools. Educational Studies, 43, 343-353. doi:10.1080/03055698.2016.1277136 
*Ishak, Z., \& Fin, L. (2013). Truants' and Teachers' Behaviors in the Classroom. Procedia-Social and Behavioral Sciences, 103, 1228-1237. doi:10.1016/j.sbspro.2013.10.451

\#Israelashvili, M. (1997). Situational determinants of school students' feelings of injustice. Elementary School Guidance \& Counseling, 31, 283-292.

\#Johnson, R. L., Green, S. K., Kim, D.-H., \& Pope, N. S. (2008). Educational leaders' perceptions about ethical practices in student evaluation. American Journal of Evaluation, 29, 520-530. doi:10.1177/1098214008322803

Kazemi, A. (2016). Examining the Interplay of Justice Perceptions, Motivation, and School Achievement among Secondary School Students. Social Justice Research, 29, 103-118. doi:10.1007/s11211-016-0261-2

*Kelly, C. A. (2002). Creating equitable classroom climates: An investigation of classroom strategies in mathematics and science instruction for developing preservice teachers' use of democratic social values. Child Study Journal, 32, 39-53.

*Kerssen-Griep, J., \& Witt, P. (2012). Instructional feedback II: How do instructor immediacy cues and facework tactics interact to predict student motivation and fairness perceptions? Communication Studies, 63, 498-517. doi:10.1080/10510974.2011.632660

*Klenowski, V. (2009). Australian Indigenous students: Addressing equity issues in assessment. Teaching Education, 20, 77-93. doi:10.1080/10476210802681741

\#Klenowski, V. (2014). Towards fairer assessment. The Australian Educational Researcher, 41, 445-470. doi:10.1007/s13384-013-0132-x

*Langan, A., Wheater, C., Shaw, E., Haines, B. J., Cullen, W. R., Boyle, J. C., . . Preziosi, R. F. (2005). Peer assessment of oral presentations: effects of student gender, university 
affiliation and participation in the development of assessment criteria. Assessment \& Evaluation in Higher Education, 30, 21-34. doi:10.1080/0260293042003243878

*Lankiewicz, H. (2014). Teacher Interpersonal Communication Abilities in the Classroom with Regard to Perceived Classroom Justice and Teacher Credibility. In M. Pawlak, J. Bielak \& A. Mystkowska-Wiertelak (Eds.), Classroom-oriented Research (pp. 101-120): Springer International Publishing.

*Lantolf, J., \& Poehner, M. (2013). The unfairness of equal treatment: objectivity in L2 testing and dynamic assessment. Educational Research and Evaluation, 19, 141-157. doi:10.1080/13803611.2013.76761

*Lemons, M., Martin, T., \& Seaton, J. (2011). Justice in the Classroom: Does Fairness Determine Student Cheating Behaviors? Journal of Academic Administration in Higher Education, 7, 17-21. Retrieved from http://jwpress.com/JAAHE/Issues/JAAHE-2011Spring.pdf\#page $=17$

\#Lenzi, M., Vieno, A., De Vogli, R., Santinello, M., Ottova, V., Baška, T., . . De Matos, M. G. (2013). Perceived teacher unfairness and headache in adolescence: a cross-national comparison. International journal of public health, 58(2), 227-235. doi: 10.1007/s00038012-0345-1

\#Liu, J., Johnson, R., \& Fan, X. (2016). A comparative study of Chinese and United States preservice teachers' perceptions about ethical issues in classroom assessment. Studies in Educational Evaluation, 48, 57-66. doi:10.1016/j.stueduc.2016.01.002

*Lizzio, A., \& Wilson, K. (2008). Feedback on assessment: Students' perceptions of quality and effectiveness. Assessment \& Evaluation in Higher Education, 33, 263-275. doi:10.1080/02602930701292548 
*Magin, D. (2001). Reciprocity as a source of bias in multiple peer assessment of group work. Studies in Higher Education, 26, 53-63. doi:10.1080/03075070020030715

\#Mauldin, R. K. (2009). Gendered perceptions of learning and fairness when choice between exam types is offered. Active Learning in Higher Education, 10, 253-264. doi:10.1177/1469787409343191

McMillan, J. H. (2013). Why we need research on classroom assessment. In J. H. McMillan (Ed.), SAGE handbook of research on classroom assessment (pp. 3-16). Thousand Oaks, CA: Sage Publications, Inc.

\#Molinari, L., Speltini, G., \& Passini, S. (2013). Do perceptions of being treated fairly increase students' outcomes? Teacher-student interactions and classroom justice in Italian adolescents. Educational Research and Evaluation, 19, 58-76.

doi:10.1080/13803611.2012.748254

*Morgan, C., \& Watson, A. (2002). The interpretative nature of teachers' assessment of students' mathematics: Issues for equity. Journal for research in mathematics education, 33, 78110. doi: $10.2307 / 749645$

*Murdock, T., Beauchamp, A., \& Hinton, A. (2008). Predictors of cheating and cheating attributions: Does classroom context influence cheating and blame for cheating? European Journal of Psychology of Education, 23, 477-492. doi:10.1007/BF03172754

*Murdock, T., Miller, A., \& Goetzinger, A. (2007). Effects of classroom context on university students' judgments about cheating: Mediating and moderating processes. Social Psychology of Education, 10, 141-169. doi:10.1007/s11218-007-9015-1 
\#Murillo, F. J., \& Hidalgo, N. (2017). Students' conceptions about a fair assessment of their learning. Studies in Educational Evaluation, 53, 10-16.

doi:10.1016/j.stueduc.2017.01.001

*Myhill, D., \& Jones, S. (2006). 'She doesn't shout at no girls': pupils' perceptions of gender equity in the classroom. Cambridge Journal of Education, 36, 99-113. doi:10.1080/03057640500491054

\#Nelson, N., Shechter, D., \& Ben-Ari, R. (2014). Procedural justice and conflict management at school. Negotiation Journal, 30, 393-419. doi:10.1111/nejo.12074

*Newstead, S. E., \& Dennis, I. (1990). Blind marking and sex bias in student assessment. Assessment and evaluation in Higher Education, 15, 132-139. doi:10.1080/0260293900150204

*Nikiforidou, Z., \& Pange, J. (2015). Fairness Through Mathematical Problem Solving in Preschool Education. In U. Gellert, J. G. Rodríguez, C. Hahn \& S. Kafoussi (Eds.), Educational Paths to Mathematics (pp. 161-171). Springer International Publishing.

Nye, E., Melendez-Torres, G., \& Bonell, C. (2016). Origins, methods and advances in qualitative meta-synthesis. Review of Education, 4, 57-79. doi:10.1002/rev3.3065

*Oppenheimer, R. (1989). Fairness in the Classroom: An Empirical Extension of the Notion of Organizational Justice. Developments in Business Simulation and Experiential Learning, 16. Retrieved from https://journals.tdl.org/absel/index.php/absel/article/view/1867

*Ortiz, S. O. (2002). Best practices in nondiscriminatory assessment. In A. Thomas \& J. Grimes (Eds.), Best Practices in School Psychology (pp. 1321-1336). Bethesda, MD: National Association of School Psychologists. 
*Panadero, E., Romero, M., \& Strijbos, J. (2013). The impact of a rubric and friendship on peer assessment: Effects on construct validity, performance, and perceptions of fairness and comfort. Studies in Educational Evaluation, 39, 195-203. doi:10.1016/j.stueduc.2013.10.005

*Paulsel, M., \& Chory-Assad, R. (2005). Perceptions of Instructor Interactional Justice as a Predictor of Student Resistance An earlier version of this paper was presented at the 2004 annual meeting of the Central States Communication Association, Cleveland, $\mathrm{OH}$ and was named a Top Four Paper in the Communication Education Interest Group. Communication Research Reports, 22, 283-291. doi:10.1080/000368105000317565

*Paulsel, M., Chory-Assad, R., \& Dunleavy, K. N. (2005). The Relationship between Student Perceptions of Instructor Power and Classroom Justice This manuscript was presented as part of the Top Paper Panel to the .... Communication Research Reports, 22, 207-215. doi:10.1080/00036810500207030

*Pepper, M., \& Pathak, S. (2008). Classroom Contribution: What Do Students Perceive as Fair Assessment? Journal of Education for Business, 360-368 doi:10.3200/JOEB.83.6.360368

*Peter, F., \& Dalbert, C. (2010). Do my teachers treat me justly? Implications of students' justice experience for class climate experience. Contemporary Educational Psychology, 35, 297 305. doi:10.1016/j.cedpsych.2010.06.001

\#Peter, F., Dalbert, C., Kloeckner, N., \& Radant, M. (2013). Personal belief in a just world, experience of teacher justice, and school distress in different class contexts. European Journal of Psychology of Education, 28, 1221-1235. doi:10.1007/s10212-012-0163-0 
\#Peter, F., Kloeckner, N., Dalbert, C., \& Radant, M. (2012). Belief in a just world, teacher justice, and student achievement: A multilevel study. Learning and individual differences, 22, 55-63. doi:10.1016/j.lindif.2011.09.011

\#Peterson, S., Childs, R., \& Kennedy, K. (2004). Written feedback and scoring of sixth-grade girls' and boys' narrative and persuasive writing. Assessing Writing, 9, 160-180. doi:10.1016/j.asw.2004.07.002

*Pnevmatikos, D., \& Trikkaliotis, I. (2012). Procedural Justice in A Classroom Where Teacher Implements Differentiated Instruction. In D. Alt \& R. Reingold (Eds.), Changes in Teachers’ Moral Role (pp. 155-163): Springer.

*Poehner, M. (2011). Dynamic assessment: Fairness through the prism of mediation. Assessment in Education: Principles, Policy \& Practice, 18, 99-112. doi:10.1080/0969594X.2011.567090

*Pope, N., Green, S. K., Johnson, R. L., \& Mitchell, M. (2009). Examining teacher ethical dilemmas in classroom assessment. Teaching and teacher education, 25, 778-782. doi:10.1016/j.tate.2008.11.013

*Resh, N. (2009). Justice in grades allocation: teachers' perspective. Social Psychology of Education, 12, 315-325. doi:10.1007/s11218-008-9073-z

\#Resh, N., \& Sabbagh, C. (2016). Justice and education. In C. Sabbagh \& M. Schmitt (Eds.), Handbook of Social Justice Theory and Research (pp. 349-367). New York: Springer.

*Reyna, C., \& Weiner, B. (2001). Justice and utility in the classroom: an attributional analysis of the goals of teachers' punishment and intervention strategies. Journal of Educational Psychology, 93, 309. doi:10.1037/0022-0663.93.2.309 
\#Robbins, T. L., \& Jeffords, B. C. (2009). Practising what we preach: Justice and ethical instruction in management education. Ethics and Education, 4, 93-102. doi:10.1080/17449640902861562

\#Rodabaugh, R. C. (1994). College Students' Perceptions of Unfairness in the Classroom. Retrieved from http://digitalcommons.unl.edu/podimproveacad/319.

*Rodabaugh, R. C., \& Kravitz, D. A. (1994). Effects of Procedural Fairness on Student Judgments of Professors. Journal on Excellence in College Teaching, 5, 67-83.

\#Sabbagh, C., \& Resh, N. (2016). Unfolding Justice Research in the Realm of Education. Social Justice Research, 29, 1-13. doi:10.1007/s11211-016-0262-1

\#Sabbagh, C., Resh, N., Mor, M., \& Vanhuysse, P. (2006). Spheres of justice within schools: Reflections and evidence on the distribution of educational goods. Social psychology of education, 9, 97-118. doi:10.1007/s11218-005-3319-9

*Sadker, M., \& Sadker, D. (1986). Sexism in the classroom: From grade school to graduate school. Phi Delta Kappan, 67, 512-515.

*Sambell, K., McDowell, L., \& Brown, S. (1997). “But is it fair?”: an exploratory study of student perceptions of the consequential validity of assessment. Studies in Educational Evaluation, 23, 349-371. doi:10.1016/S0191-491X(97)86215-3

Sanders, J. R., Hills, J., Nitko, A., Merwin, J., Trice, C., Dianda, M., \& Schneider, J. (1990). Standards for teacher competence in educational assessment of students. Educational Measurement: issues and practices, 30-32.

*Sayre, S. A., \& Ankney, P. (1976). Piaget, Justice and Behavior in the Classroom. Childhood Education, 52, 238-241. doi:10.1080/00094056.1976.10727490 
*Schissel, J. L. (2014). Classroom use of test accommodations: Issues of access, equity, and conflation. Current Issues in Language Planning, 15, 282-295. doi:10.1080/14664208.2014.915458

*Schmidt, T., Houston, M., Bettencourt, L., \& Boughton, P. D. (2003). The impact of voice and justification on students' perceptions of professors' fairness. Journal of Marketing Education, 25, 177-186. doi:10.1177/0273475303254024

*Scott, S., Webber, C. F., Lupart, J. L., Aitken, N., \& Scott, D. E. (2014). Fair and equitable assessment practices for all students. Assessment in Education: Principles, Policy \& Practice, 21, 52-70. doi:10.1080/0969594X.2013.776943

\#Seevers, M. T., Rowe, W. J., \& Skinner, S. J. (2014). Praise in public, criticize in private? An assessment of performance feedback transparency in a classroom setting. Marketing Education Review, 24, 85-100. doi:10.2753/MER1052-8008240201

Shepard, L. (2001). The role of classroom assessment in teaching and learning. In V. Richardson (Ed.), Handbook of research on teaching (Vol. 4th edition, pp. 1066-1101). Washington, DC: AERA.

*Siegel, M. (2007). Striving for equitable classroom assessments for linguistic minorities: Strategies for and effects of revising life science items. Journal of Research in Science Teaching, 44, 864-881. doi:10.1002/tea.20176

*Siegel, M. (2014). Developing Preservice Teachers' Expertise in Equitable Assessment for English Learners. Journal of Science Teacher Education, 25, 289-308.

doi:10.1007/s10972-013-9365-9 
*Siegel, M., Menon, D., Sinha, S., Promyod, N., Wissehr, C., \& Halverson, K. L. (2014). Equitable written assessments for english language learners: how scaffolding helps. Journal of Science Teacher Education, 25, 681-708. doi:10.1007/s10972-014-9392-1

*Siegel, M., Wissehr, C., \& Halverson, K. (2008). Sounds like success: A framework for equitable assessment. The Science Teacher, 75, 43-46.

*Sivan, A. (2000). The implementation of peer assessment: an action research approach. Assessment in Education: Principles, Policy \& Practice, 7, 193-213. doi:10.1080/713613328

*Spear, M. G. (1984). Sex bias in science teachers' ratings of work and pupil characteristics. European Journal of Science Education, 6, 369-377. doi:10.1080/0140528840060407

*Suskie, L. (2000). Fair assessment practices: giving students equitable opportunities to demonstrate learning. American Association for Higher Education. Retrieved from http://www.ubc.ca/okanagan/ctl/_shared/assets/FairAssessmentPractices12732.pdf

*Sussman, L. (1975). A theoretical analysis of equity and its relationship to student evaluation. Southern Journal of Communication, 40, 321-334. doi:10.1080/10417947509372275

*Tata, J. (1999). Grade distributions, grading procedures, and students' evaluations of instructors: A justice perspective. The Journal of Psychology: Interdisciplinary and Applied, 133, 263-271. doi:10.1080/00223989909599739

*Tata, J. (2005). The influence of national culture on the perceived fairness of grading procedures: A comparison of the United States and China. The Journal of psychology, 139, 401-412. doi:10.3200/JRLP.139.5.401-412

*Thorkildsen, T. A. (1989a). Justice in the Classroom: The Student's View. Child Development, 60, 323-334. doi:10.2307/1130979 
\#Thorkildsen, T. A. (1989b). Pluralism in children's reasoning about social justice. Child Development, 965-972.

\#Thorkildsen, T. A. (1993). Those who can, tutor: High-ability students' conceptions of fair ways to organize learning. Journal of Educational Psychology, 85, 182. doi:10.1037/00220663.85 .1 .182

*Thorkildsen, T. A. (1994a). Through Students' Eyes: A Fair Classroom. Update on Law-Related Education, 18, 56-62.

\#Thorkildsen, T. A. (1994b). Toward a fair community of scholars: Moral education as the negotiation of classroom practices. Journal of Moral Education, 23, 371-385. doi:10.1080/0305724940230401

*Thorkildsen, T. A., Nolen, S. B., \& Fournier, J. (1994). What is fair? Children's critiques of practices that influence motivation. Journal of Educational Psychology, 86, 475. doi:10.1037/0022-0663.86.4.47

*Tierney, R. (2013). Fairness in classroom assessment. In J. H. McMillan (Ed.), Sage handbook of research on classroom assessment (pp. 125-144). Thousand Oaks, CA: SAGE Publications.

*Tierney, R. (2014). Fairness as a multifaceted quality in classroom assessment. Studies in Educational Evaluation, 43, 55-69. doi:10.1016/j.stueduc.2013.12.003

\#Tierney, R. (2015). Altered grades: A grey zone in the ethics of classroom assessment. Assessment Matters, 8, 5-30. doi:10.18296/am.0002

\#Tierney, R. (2016). Fairness in Educational Assessment. In M. A. Peters (Ed.), Encyclopedia of Educational Philosophy and Theory (pp. 1-6). Singapore: Springer Singapore. 
\#Tillema, H., Leenknecht, M., \& Segers, M. (2011). Assessing assessment quality: Criteria for quality assurance in design of (peer) assessment for learning-a review of research studies. Studies in Educational Evaluation, 37, 25-34. doi: 10.1016/j.stueduc.2011.03.004

*Tomul, E., Çelik, K., \& Tas, A. (2012). Justice in the Classroom: Evaluation of Teacher Behaviors According to Students' Perceptions. Eurasian Journal of Educational Research, 48, 59-72.

Torok, S., McMorris, R., \& Lin, W. (2004). Is humor an appreciated teaching tool? perceptions of professors' teaching styles and use of humor. College Teaching, 52, 14-20. doi:10.3200/CTCH.52.1.14-20

*Uludag, O. (2014). Fair and Square: How does Perceptions of Fairness is Associated to Aggression? Procedia-Social and Behavioral Sciences, 143, 504-508. doi:10.1016/j.sbspro.2014.07.424

*Vallade, J., Martin, M., \& Weber, K. (2014). Academic Entitlement, Grade Orientation, and Classroom Justice as Predictors of Instructional Beliefs and Learning Outcomes. Communication Quarterly, 62, 497-517. doi:10.1080/01463373.2014.949386

*Volante, L. (2006). Reducing bias in classroom assessment and evaluation. Orbit, 36(2), 34-36.

*Webb, N. M., Nemer, K. M., Chizhik, A. W., \& Sugrue, B. (1998). Equity issues in collaborative group assessment: Group composition and performance. American Educational Research Journal, 35, 607-651. doi:10.3102/00028312035004607

*Welch, A. B. (2000). Responding to student concerns about fairness. Teaching Exceptional Children, 33, 36-40. doi:10.1177/004005990003300205 
*Wendorf, C., \& Alexander, S. (2005). The influence of individual-and class-level fairnessrelated perceptions on student satisfaction. Contemporary Educational Psychology, 30, 190-206. doi:10.1016/j.cedpsych.2004.07.003

\#Whalen, D. J., \& Koernig, S. K. (2009). Maintaining Fairness When a Student Goes Afoul of Classroom Rules: A Procedural Justice Model. Marketing Education Review, 19(2), 2733. doi:10.1080/10528008.2009.11489071

*Whitley, B., Perkins, D. V., Balogh, D. W., Keith-Speigel, P., \& Wittig, A. F. (2000). Fairness in the classroom. APS Observer, 13, 24-27.

Wiliam, D. (2011). What is assessment for learning? Studies in Educational Evaluation, 37, 314. doi:10.1016/j.stueduc.2011.03.001

Xu, Y., \& Brown, G. T. (2016). Teacher assessment literacy in practice: A reconceptualization. Teaching and teacher education, 58, 149-162. doi:10.1016/j.tate.2016.05.010

*Young, L., Horan, S., \& Frisby, B. (2013). Fair and square? An examination of classroom justice and relational teaching messages. Communication Education, 62, 333-351. doi:10.1080/03634523.2013.800216

*Yung, B., \& Yung, B. (2001). Three views of fairness in a school-based assessment scheme of practical work in biology. International Journal of Science Education, 23, 985-1005. doi:10.1080/09500690010017129 


\section{Tables and Figures}

Table 1 Themes and demographic information of the included studies in assessment domain

\begin{tabular}{|c|c|c|c|}
\hline Study & $\begin{array}{l}\text { Time of } \\
\text { publication }\end{array}$ & Context of the study & $\begin{array}{l}\text { Research design } \\
\text { (i.e., mixed, } \\
\text { quan, qual, } \\
\text { theoretical) }\end{array}$ \\
\hline \multicolumn{4}{|c|}{ Theme 1: Opportunity for learning and access to demonstrate learning } \\
\hline Gipps & 1995 & & Theoretical \\
\hline Gipps and Stobart & 2009 & & Theoretical \\
\hline Tierney & 2013 & & Theoretical \\
\hline Tierney & 2016 & & Theoretical \\
\hline Poehner & 2011 & & Theoretical \\
\hline Lantolf \& Poehner & 2013 & & Theoretical \\
\hline Suskie & 2002 & & Theoretical \\
\hline Volante & 2006 & & Theoretical \\
\hline Camilli & 2013 & & Theoretical \\
\hline Klenowski & 2014 & & Theoretical \\
\hline Camilli & 2006 & & Theoretical \\
\hline Cowie & 2015 & & Theoretical \\
\hline Mauldin & 2009 & US & Quantitative \\
\hline Duffield \& Spencer & 2002 & UK & Quantitative \\
\hline Yung \& Yung & 2001 & Hong Kong & Qualitative \\
\hline Murillo \& Hidalgo & 2017 & Spain & Qualitative \\
\hline \multicolumn{4}{|l|}{ Theme 2: Transparency, consistency, and justification } \\
\hline Camilli & 2006 & & Theoretical \\
\hline Gipps and Stobart & 2009 & & Theoretical \\
\hline Tierney & 2013 & & Theoretical \\
\hline Suskie & 2002 & & Theoretical \\
\hline Murillo \& Hidalgo & 2017 & Spain & Qualitative \\
\hline Morgan, \& Watson & 2002 & UK & Qualitative \\
\hline Alm \& Colnerud & 2015 & Sweden & Qualitative \\
\hline Carless & 2006 & Hong Kong & Mixed \\
\hline Lizzio \& Wilson & 2008 & Australia & Mixed \\
\hline \multicolumn{4}{|l|}{ Theme 3: Accommodations } \\
\hline Abedi, Hofstetter, \& Lord & 2004 & & Theoretical \\
\hline Siegel, Wissehr, \& Halverson & 2008 & & Theoretical \\
\hline Ortiz & 2002 & & Theoretical \\
\hline Scott, Webber, Lupart, Aitken \& Scott & 2014 & & Theoretical \\
\hline Siegel & 2007 & US & Quantitative \\
\hline Siegel, Menon, Sinha, Promyod, Wissehr, \& Halverson & 2014 & US & Qualitative \\
\hline Schissel & 2014 & US & Qualitative \\
\hline Siegel & 2014 & US & Qualitative \\
\hline \multicolumn{4}{|c|}{ Theme 4: Do no harm and constructive classroom environment } \\
\hline Klenowski & 2009 & & Theoretical \\
\hline Tierney & 2013 & & Theoretical \\
\hline Tierney & 2016 & & Theoretical \\
\hline Cowie & 2015 & & Theoretical \\
\hline Scott, Webber, Lupart, Aitken \& Scott & 2014 & & Theoretical \\
\hline Flores, Simão, Barros \& Pereira & 2014 & Portugal & Quantitative \\
\hline Pope, Green, Johnson, \& Mitchell & 2009 & US & Quantitative \\
\hline Green, Johnson, Kim, \& Pope & 2007 & US & Quantitative \\
\hline Johnson, Green, Kim, \& Pope & 2008 & US & Quantitative \\
\hline Liu, Johnson \& Fan & 2016 & US \& China & Quantitative \\
\hline Sambell, McDowell \& Brown & 1997 & UK & Qualitative \\
\hline Tierney & 2014 & Canada & Qualitative \\
\hline Aitken & 2012 & Canada & Qualitative \\
\hline Murillo \& Hidalgo & 2017 & Spain & Qualitative \\
\hline Carless & 2006 & Hong Kong & Mixed \\
\hline Lizzio \& Wilson & 2008 & Australia & Mixed \\
\hline \multicolumn{4}{|l|}{ Theme 5: Avoid score pollution } \\
\hline Scott, Webber, Lupart, Aitken \& Scott & 2014 & & Theoretical \\
\hline Pope, Green, Johnson, \& Mitchell & 2009 & US & Quantitative \\
\hline Crosthwaite, Bailey \& Meeker & 2015 & South Korea & Quantitative \\
\hline
\end{tabular}


Reconceptualizing Assessment Fairness

\begin{tabular}{|c|c|c|c|}
\hline Green, Johnson, Kim, \& Pope & 2007 & US & Quantitative \\
\hline Johnson, Green, Kim, \& Pope & 2008 & US & Quantitative \\
\hline Liu, Johnson \& Fan & 2016 & US \& China & Quantitative \\
\hline Peterson, Childs, \& Kennedy & 2004 & Canada & Quantitative \\
\hline Murillo \& Hidalgo & 2017 & Spain & Qualitative \\
\hline Sambell, McDowell \& Brown & 1997 & UK & Qualitative \\
\hline Tierney & 2015 & Canada & Qualitative \\
\hline Alm \& Colnerud & 2015 & Sweden & Qualitative \\
\hline \multicolumn{4}{|l|}{ Theme 6: Group work and peer assessment } \\
\hline Fellenz & 2006 & Ireland & Theoretical \\
\hline Tillema, Leenknecht \& Segers & 2011 & & Theoretical \\
\hline Falchikov \& Magin & 1997 & Australia & Quantitative \\
\hline Barfield & 2003 & US & Quantitative \\
\hline $\begin{array}{l}\text { Langan, Wheater, Shaw, Haines, Cullen, Boyle, Penney, } \\
\text { Oldekop, Ashcroft, Lockey \& Preziosi }\end{array}$ & 2005 & UK & Quantitative \\
\hline Magin & 2001 & Australia & Quantitative \\
\hline Gweon, Jun, Finger, \& Penstein Rose & 2017 & South Korea & Quantitative \\
\hline Webb, Nemer, Chizhik, \& Sugrue & 1998 & US & Quantitative \\
\hline Panadero, Romero, \& Strijbos & 2013 & Spain & Quantitative \\
\hline Sivan & 2000 & Hong Kong & Mixed \\
\hline
\end{tabular}

Table 2 Themes and demographic information of the included studies in non-assessment domain

\begin{tabular}{|c|c|c|c|}
\hline Study & $\begin{array}{l}\text { Time of } \\
\text { publication }\end{array}$ & Context of the study & $\begin{array}{l}\text { Research design } \\
\text { (i.e., mixed, quan, } \\
\text { qual, theoretical) }\end{array}$ \\
\hline \multicolumn{4}{|l|}{ Theme 1: Sex Bias } \\
\hline Jones, \& Dindia & 2004 & & Theoretical \\
\hline Sadker, \& Sadker & 1986 & & Theoretical \\
\hline Newstead \& Dennis & 1990 & UK & Quantitative \\
\hline Hazel, Logan, \& Gallagher & 1997 & Australia & Quantitative \\
\hline Spear & 1984 & UK & Quantitative \\
\hline Duffy, Warren, \& Walsh & 2001 & Canada & Quantitative \\
\hline Brady, \& Eisler & 1999 & US & Quantitative \\
\hline Altermatt, Jovanovic, Perry & 1998 & US & Quantitative \\
\hline Myhill \& Jones & 2006 & UK & Qualitative \\
\hline Kelly & 2002 & US & Mixed \\
\hline \multicolumn{4}{|l|}{ Theme 2: Distributive Justice } \\
\hline Sayre \& Ankney & 1976 & & Theoretical \\
\hline Whitley, Perkins, Balogh, Keith-Spiegel, \& Wittig & 2000 & & Theoretical \\
\hline Welch & 2000 & & Theoretical \\
\hline Sabbagh, Resh, Mor, \& Vanhuysse & 2006 & & Theoretical \\
\hline Sussman & 1975 & & Theoretical \\
\hline Thorkildsen & $1994 a$ & & Theoretical \\
\hline Thorkildsen & $1994 b$ & & Theoretical \\
\hline Hannay & 2014 & & Theoretical \\
\hline Resh \& Sabbagh & 2016 & & Theoretical \\
\hline Sabbagh \& Resh & 2016 & & Theoretical \\
\hline Grace & 2017 & & Theoretical \\
\hline Nikiforidou \& Pange & 2015 & Greece & Quantitative \\
\hline Lemons, Martin, \& Seaton & 2011 & US & Quantitative \\
\hline Murdock, Beauchamp, \& Hinton & 2008 & US & Quantitative \\
\hline Uludag & 2014 & Cyprus & Quantitative \\
\hline Gotlieb & 2009 & US & Quantitative \\
\hline Cronen \& Fuller & 1976 & US & Quantitative \\
\hline Bear \& Fink & 1991 & US & Quantitative \\
\hline Tomul, Celik, \& Tas & 2012 & Turkey & Quantitative \\
\hline Gorard & 2012 & England, Belgium, Italy, France, Czech Republic & Quantitative \\
\hline Chory- Assad & 2002 & US & Quantitative \\
\hline Chory- Assad, \& Paulsel & $2004 a$ & US & Quantitative \\
\hline Paulsel, Chory-Assad \& Dunleavy & 2005 & US & Quantitative \\
\hline Horan \& Myers & 2009 & US & Quantitative \\
\hline Holmgren and Bolkan & 2014 & US & Quantitative \\
\hline Young, Horan and Frisby & 2013 & US & Quantitative \\
\hline Vallade, Martin, and Weber & 2014 & US & Quantitative \\
\hline Berti, Molinari, Speltini & 2010 & Italy & Quantitative \\
\hline Claus, Chory \& Malachowski & 2012 & US & Quantitative \\
\hline Tata & 1999 & US & Quantitative \\
\hline
\end{tabular}


Reconceptualizing Assessment Fairness

\begin{tabular}{|c|c|c|c|}
\hline Lankiewicz & 2014 & Poland & Quantitative \\
\hline Pnevmatikos, \& Trikkaliotis & 2012 & Context is not given & Quantitative \\
\hline Colquitt & 2001 & US & Quantitative \\
\hline Horan, Chory, Carton, Miller \& Raposo & 2013 & US & Quantitative \\
\hline Pepper \& Pathak & 2008 & US & Quantitative \\
\hline Wendorf, \& Alexander & 2005 & US & Quantitative \\
\hline Gordon, \& Fay & 2010 & US & Quantitative \\
\hline Cherry, Ordóñez, \& Gilliland & 2003 & US & Quantitative \\
\hline Resh & 2009 & Isreal & Quantitative \\
\hline Ishak \& Fin & 2013 & Malaysia & Quantitative \\
\hline Davison, Mishra, Bing, \& Frink & 2014 & US & Quantitative \\
\hline Peter, \& Dalbert & 2010 & Germany & Quantitative \\
\hline Reyna \& Weiner & 2001 & US & Quantitative \\
\hline Donat, Dalbert \& Kamble, & 2014 & Germany & Quantitative \\
\hline Peter, Dalbert, Kloeckner, \& Radant & 2013 & Germany & Quantitative \\
\hline Peter, Kloeckner, Dalbert \& Radant & 2012 & Germany & Quantitative \\
\hline Rodabaugh & 1994 & US & Quantitative \\
\hline Thorkildsen & $1989 b$ & US & Quantitative \\
\hline Lenzi, Vieno, Vogli, Santinello, Ottova, Bas`ka, & 2012 & 21 European and & Quantitative \\
\hline Griebler, Gobina \& Matos & & North-American countries & \\
\hline Gouveia-Pereira, Vala, Palmonari, \& Rubini & 2003 & Context is not given & Quantitative \\
\hline Alt & 2015 & Israel & Quantitative \\
\hline Bempechat, Ronfard, Mirny, Li \& Holloway & 2013 & Russia & Qualitative \\
\hline Horan, Chory \& Goodboy & 2010 & US & Qualitative \\
\hline Houston \& Bettencourt & 1999 & US & Qualitative \\
\hline Čiuladienè \& Račelytė & 2016 & Lithuania & Qualitative \\
\hline Israelashvili & 1997 & Israel & Qualitative \\
\hline Evans, Salisbury, Palombaro, \& Goldberg & 1994 & US & Mixed \\
\hline Thorkildsen & $1989 \mathrm{a}$ & US & Mixed \\
\hline Chory, Horan, \& Houser & 2017 & US & Mixed \\
\hline Alt \& Itzkovich & 2015 & Israel & Mixed \\
\hline Ehrhardt, Pretsch, Herrmann, \& Schmitt & 2016 & Germany & Mixed \\
\hline Thorkildsen & 1993 & US & Mixed \\
\hline Robbins \& Jeffords & 2009 & US & Mixed \\
\hline \multicolumn{4}{|l|}{ Theme 3: Procedural Justice } \\
\hline Whalen \& Koernig & 2009 & & Theoretical \\
\hline Whitley, Perkins, Balogh, Keith-Spiegel, \& Wittig & 2000 & & Theoretical \\
\hline Sabbagh, Resh, Mor, \& Vanhuysse & 2006 & & Theoretical \\
\hline Sabbagh \& Resh & 2016 & & Theoretical \\
\hline Grace & 2017 & & Theoretical \\
\hline Resh \& Sabbagh & 2016 & & Theoretical \\
\hline Abdelzadeh, Zetterberg, \& Ekman & 2014 & Sweden & Quantitative \\
\hline Rodabaugh, Kravitz & 1994 & US & Quantitative \\
\hline Oppenheimer & 1989 & US & Quantitative \\
\hline Tata & 2005 & US and China & Quantitative \\
\hline Schmidt, Houston, Bettencourt, \& Boughton & 2003 & US & Quantitative \\
\hline Duplaga \& Astani & 2010 & US & Quantitative \\
\hline Nelson, Shechter, \& Ben-Ari & 2014 & Israel & Quantitative \\
\hline Lemons, Martin, \& Seaton & 2011 & US & Quantitative \\
\hline Uludag & 2014 & Cyprus & Quantitative \\
\hline Chory- Assad & 2002 & US & Quantitative \\
\hline Chory- Assad, \& Paulsel & $2004 a$ & US & Quantitative \\
\hline Paulsel, Chory-Assad \& Dunleavy & 2005 & US & Quantitative \\
\hline Horan \& Myers & 2009 & US & Quantitative \\
\hline Holmgren and Bolkan & 2014 & US & Quantitative \\
\hline Young, Horan and Frisby & 2013 & US & Quantitative \\
\hline Vallade, Martin, and Weber & 2014 & US & Quantitative \\
\hline Berti, Molinari, Speltini & 2010 & Italy & Quantitative \\
\hline Claus, Chory \& Malachowski & 2012 & US & Quantitative \\
\hline Tata & 1999 & US & Quantitative \\
\hline Lankiewicz & 2014 & Poland & Quantitative \\
\hline Pnevmatikos, \& Trikkaliotis & 2012 & Context is not given & Quantitative \\
\hline Colquitt & 2001 & US & Quantitative \\
\hline Horan, Chory, Carton, Miller \& Raposo & 2013 & US & Quantitative \\
\hline Pepper \& Pathak & 2008 & US & Quantitative \\
\hline Wendorf, \& Alexander & 2005 & US & Quantitative \\
\hline Gordon, \& Fay & 2010 & US & Quantitative \\
\hline Seevers, Rowe, \& Skinner & 2014 & US & Quantitative \\
\hline Peter, \& Dalbert & 2010 & Germany & Quantitative \\
\hline Donat, Dalbert \& Kamble, & 2014 & Germany & Quantitative \\
\hline
\end{tabular}


Reconceptualizing Assessment Fairness

\begin{tabular}{|c|c|c|c|}
\hline Peter, Dalbert, Kloeckner, \& Radant & 2013 & Germany & Quantitative \\
\hline Peter, Kloeckner, Dalbert \& Radant & 2012 & Germany & Quantitative \\
\hline Rodabaugh & 1994 & US & Quantitative \\
\hline $\begin{array}{l}\text { Lenzi, Vieno, Vogli, Santinello, Ottova, Bas`ka, } \\
\text { Griebler, Gobina \& Matos }\end{array}$ & 2012 & $\begin{array}{l}21 \text { European and } \\
\text { North-American countries }\end{array}$ & Quantitative \\
\hline Gouveia-Pereira, Vala, Palmonari, \& Rubini & 2003 & Context is not given & Quantitative \\
\hline Alt & 2015 & Israel & Quantitative \\
\hline Čiuladienè \& Račelytė & 2016 & Lithuania & Qualitative \\
\hline Israelashvili & 1997 & Israel & Qualitative \\
\hline Bempechat, Ronfard, Mirny, Li \& Holloway & 2013 & Russia & Qualitative \\
\hline Horan, Chory \& Goodboy & 2010 & US & Qualitative \\
\hline Houston \& Bettencourt & 1999 & US & Qualitative \\
\hline Chory, Horan, \& Houser & 2017 & US & Mixed \\
\hline Ehrhardt, Pretsch, Herrmann, \& Schmitt & 2016 & Germany & Mixed \\
\hline Alt \& Itzkovich & 2015 & Israel & Mixed \\
\hline Robbins \& Jeffords & 2009 & US & Mixed \\
\hline \multicolumn{4}{|l|}{ Theme 4: Interactional Justice } \\
\hline Boaler & 2008 & & Theoretical \\
\hline Campbell & 1997 & & Theoretical \\
\hline Colnerud & 2006 & & Theoretical \\
\hline Sabbagh, Resh, Mor, \& Vanhuysse & 2006 & & Theoretical \\
\hline Whitley, Perkins, Balogh, Keith-Spiegel, \& Wittig & 2000 & & Theoretical \\
\hline Hannay & 2014 & & Theoretical \\
\hline Kerssen-Griep \&Witt & 2012 & US & Quantitative \\
\hline Boysen, Vogel, Cope, \& Hubbard & 2009 & US & Quantitative \\
\hline Boysen & 2012 & US & Quantitative \\
\hline Oppenheimer & 1989 & US & Quantitative \\
\hline Tata & 2005 & US and China & Quantitative \\
\hline Schmidt, Houston, Bettencourt, \& Boughton & 2003 & US & Quantitative \\
\hline Colquitt & 2001 & US & Quantitative \\
\hline Horan, Chory, Carton, Miller \& Raposo & 2013 & US & Quantitative \\
\hline Pepper \& Pathak & 2008 & US & Quantitative \\
\hline Wendorf, \& Alexander & 2005 & US & Quantitative \\
\hline Gordon, \& Fay & 2010 & US & Quantitative \\
\hline Peter, \& Dalbert & 2010 & Germany & Quantitative \\
\hline Donat, Dalbert \& Kamble, & 2014 & Germany & Quantitative \\
\hline Peter, Dalbert, Kloeckner, \& Radant & 2013 & Germany & Quantitative \\
\hline Peter, Kloeckner, Dalbert \& Radant & 2012 & Germany & Quantitative \\
\hline Lankiewicz & 2014 & Poland & Quantitative \\
\hline Berti, Molinari, Speltini & 2010 & Italy & Quantitative \\
\hline Claus, Chory \& Malachowski & 2012 & US & Quantitative \\
\hline Paulsel, Chory-Assad \& Dunleavy & 2005 & US & Quantitative \\
\hline Horan \& Myers & 2009 & US & Quantitative \\
\hline Holmgren and Bolkan & 2014 & US & Quantitative \\
\hline Young, Horan and Frisby & 2013 & US & Quantitative \\
\hline Molinari, Speltini, \& Passini & 2013 & Italy & Quantitative \\
\hline Berti, Mameli, Speltini, \& Molinari & 2016 & Italy & Quantitative \\
\hline Uludag & 2014 & Cyprus & Quantitative \\
\hline Lenzi, Vieno, Vogli, Santinello, Ottova, Bas``ka, & 2012 & 21 European and & Quantitative \\
\hline Griebler, Gobina \& Matos & & North-American countries & \\
\hline Gouveia-Pereira, Vala, Palmonari, \& Rubini & 2003 & Context is not given & Quantitative \\
\hline Alt & 2015 & Israel & Quantitative \\
\hline Tomul, Celik, \& Tas & 2012 & Turkey & Quantitative \\
\hline Gorard & 2012 & England, Belgium, Italy, France, the Czech Republic & Quantitative \\
\hline Murdock, Miller \& Goetzinger & 2007 & 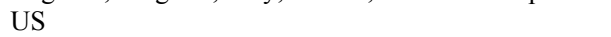 & Quantitative \\
\hline Chory- Assad, \& Paulsel & $2004 b$ & US & Quantitative \\
\hline Paulsel, \& Chory- Assad & 2005 & US & Quantitative \\
\hline Chory & 2007 & US & Quantitative \\
\hline Čiuladienė \& Račelytė & 2016 & Lithuania & Qualitative \\
\hline Horan, Chory \& Goodboy & 2010 & US & Qualitative \\
\hline Bempechat, Ronfard, Mirny, Li \& Holloway & 2013 & Russia & Qualitative \\
\hline Israelashvili & 1997 & Israel & Qualitative \\
\hline Buttner & 2004 & US & Qualitative \\
\hline Boysen, \& Vogel & 2009 & US & Qualitative \\
\hline Houston \& Bettencourt & 1999 & US & Qualitative \\
\hline Chory, Horan, \& Houser & 2017 & US & Mixed \\
\hline Ehrhardt, Pretsch, Herrmann, \& Schmitt & 2016 & Germany & Mixed \\
\hline Alt \& Itzkovich & 2015 & Israel & Mixed \\
\hline Robbins \& Jeffords & 2009 & US & Mixed \\
\hline
\end{tabular}


Reconceptualizing Assessment Fairness

\begin{tabular}{llll}
\hline Theme 5: Pedagogy & & & Theoretical \\
\hline Resh \& Sabbagh & 2016 & & Theoretical \\
Sabbagh, Resh, Mor, \& Vanhuysse & 2006 & & Theoretical \\
Sabbagh \& Resh & 2016 & US & Quantitative \\
Rodabaugh & 1994 & US & Quantitative \\
Chory & 2007 & Quantitative \\
Lankiewicz & 2014 & Poland & Quantitative \\
Murdock, Beauchamp, \& Hinton & 2008 & US & Qualitative \\
Bempechat, Ronfard, Mirny, Li \& Holloway & 2013 & Russia & Quantitative \\
\hline Theme 6: Students' Fairness-related Beliefs & & & Quantitative \\
\hline Duplaga \& Astani & 2010 & US & Quantitative \\
Peter, \& Dalbert & 2010 & Germany & Quantitative \\
Alt & 2015 & Israel & Quantitative \\
Donat, Dalbert \& Kamble, & 2014 & Germany & Quantitative \\
Berti, Mameli, Speltini, \& Molinari & 2016 & Italy & Quantitative \\
Human-Vogel \& Morkel & 2017 & South Africa & \\
Peter, Dalbert, Kloeckner, \& Radant & 2013 & Germany & Quantitative \\
& & & Mixed \\
Peter, Kloeckner, Dalbert \& Radant & 2012 & Germany & Mixed \\
Alt \& Itzkovich & 2015 & Israel & Theoretical \\
Thorkildsen, Nolen \& Fournier & 1994 & US & Quantitative \\
\hline Theme 7: Group Work and Peer Assessment & & & Quantitative \\
\hline Hannay & 2014 & & Portugal \\
Carvalho & 2013 & US & Qualitative \\
Davison, Mishra, Bing, \& Frink & & US & \\
\hline Theme 8: Instructional Accommodation & & \\
\hline Baker \& Scanlon & 2014 & \\
\hline
\end{tabular}




\section{Figure 1}

Classroom assessment fairness in the intersection of four elements of classroom practice

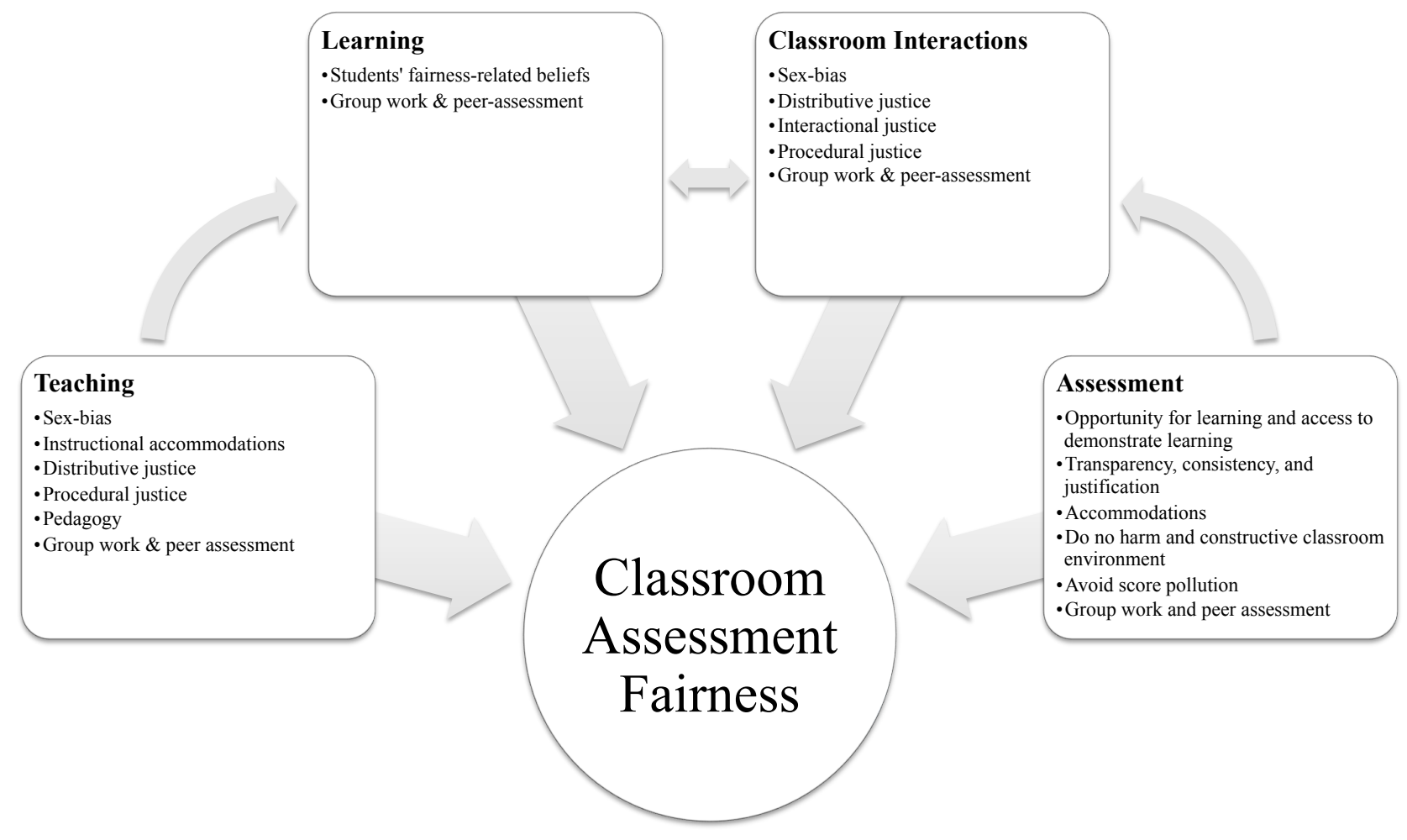

